OPEN ACCESS

Edited by:

Kequan Yu,

Tongji University, China

Reviewed by: He Zhu,

University of Michigan, United States Tao Ding,

Tongji University, China

*Correspondence: Shan Gao

gaoshan@hit.edu.cn

Specialty section:

This article was submitted to

Structural Materials,

a section of the journal

Frontiers in Materials

Received: 22 August 2021 Accepted: 11 October 2021

Published: 11 November 2021

Citation:

Wang W, Wei W, Gao S, Chen G, Yuan J and Li Y (2021) Agricultural and

Aquaculture Wastes as Concrete

Components: A Review.

Front. Mater. 8:762568.

doi: 10.3389/fmats.2021.762568

\section{Agricultural and Aquaculture Wastes as Concrete Components: A Review}

\author{
Wei Wang ${ }^{1}$, Wuyou Wei ${ }^{1}$, Shan Gao ${ }^{2,3 *}$, Guiming Chen ${ }^{1}$, Jian Yuan ${ }^{1}$ and $Y u L^{3,4}$ \\ ${ }^{1} X i$ 'an Research Institute of High-Tech, Xi'an, China, ${ }^{2}$ School of Civil Engineering, Harbin Institute of Technology, Harbin, China, \\ ${ }^{3}$ School of Civil Engineering, Xijing University, Xi'an, China, ${ }^{4}$ Gansu Institute of Architectural Design and Research Institute, \\ Lanzhou, China
}

The application of agricultural and aquaculture waste in concrete greatly reduces the pressure on the ecological environment brought by traditional concrete production. The use of agricultural and aquaculture wastes as cement replacement, aggregate replacement and fiber reinforcement has showed great potential. Making full use of these wastes can help the development of sustainable concrete. This paper provides an objective evaluation and summary of agricultural waste and aquaculture waste in green concrete. Agricultural waste is divided into natural plant fiber, agricultural waste ash and multi-application waste according to useful function and alternative methods, such as sisal fiber, olive waste ash, and bamboo. Aquaculture waste mainly refers to some shells such as oyster shell. This paper analyzes the advantages and disadvantages of agricultural and aquaculture waste concrete applications that have been reported and shows how different agricultural and aquaculture wastes are made in concrete. The selection of appropriate treatment methods and usage scenarios is extremely important for agricultural and aquaculture waste concrete, which can determine whether the concrete has reliable performance. This paper will lay a foundation for the progress of waste concrete and provide reliable help for the development of environmental protection concrete.

Keywords: agricultural waste, aquaculture waste, concrete, cement, performance

\section{INTRODUCTION}

Concrete is one of the most used building materials in the world. The global annual concrete consumption is close to 17.5 billion tons, in which the required aggregate and cement are about 13 billion tons and 2.6 billion tons, respectively (Bo et al., 2018). Excessive use of quarrying and mining to collect aggregates leads to the exhaustion of natural resources and directly causes negative impacts on the ecological environment, such as landscape destruction and ecosystem destruction, and pollutions (Blankendaal et al., 2014). At the same time, cement, the main component of mortar, account for $74-81 \%$ of the total carbon dioxide emissions from concrete production (Flower and Sanjayan, 2007). Cement production processes emit about 1 billion tons of $\mathrm{CO}_{2}$ a year (Salmabanu et al., 2019).

In order to mitigate environmental damage by concrete industry, variable alternatives for both aggregate and cement have been investigated extensively in the past decades. For instance, recycled aggregates and fine powders from waste concrete could be employed for preparation of fresh concrete with satisfying performance. Industrial wastes such as fly ash (Singh and Siddique, 2015), slag (Mo et al., 2015), bottom ash (Zhang and Poon, 2015), etc. have also been widely used in 


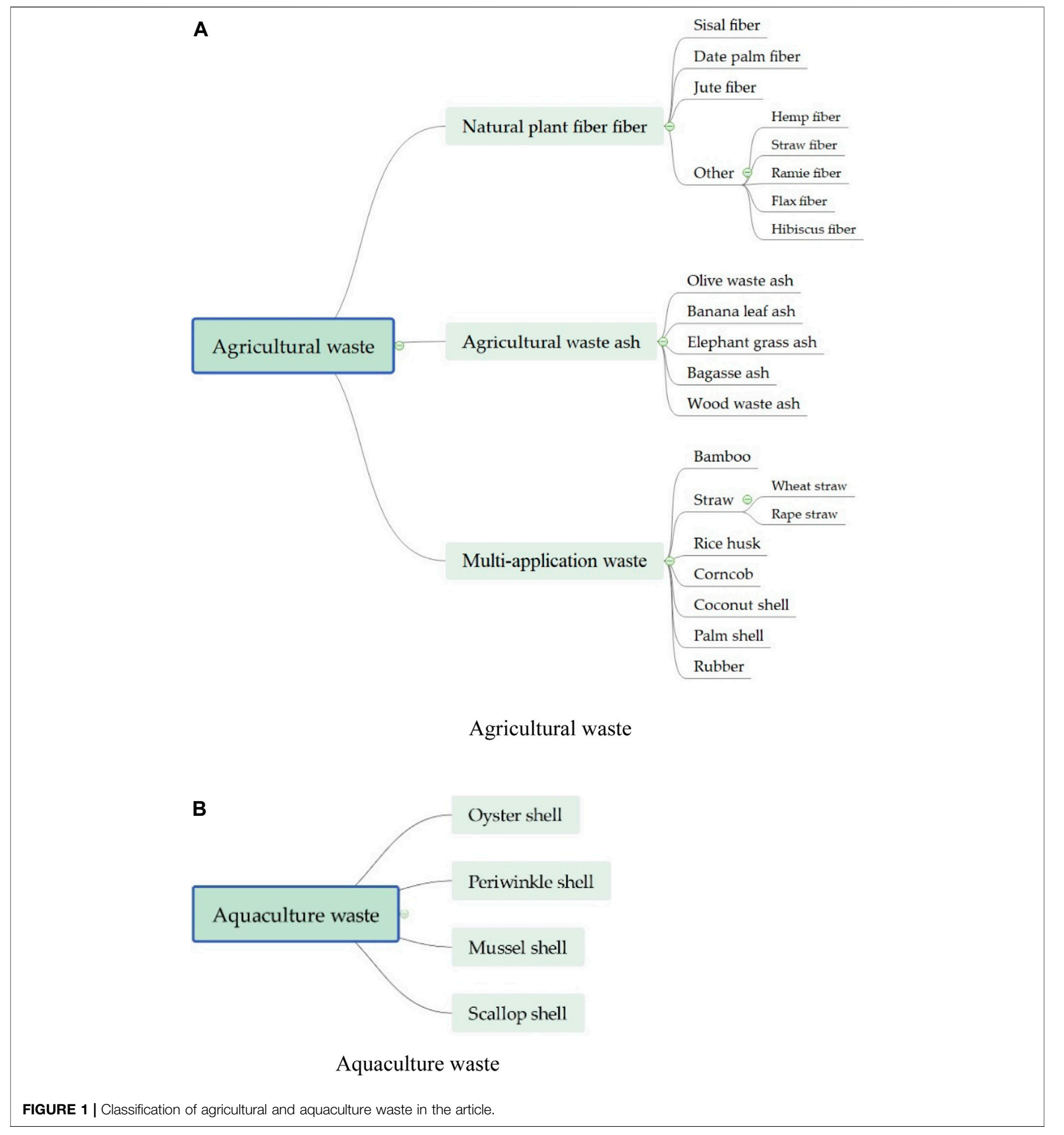

concrete. As an emerging substitute of cement, limestone calcined clay cements have drawn more and more attentions from building material industry (Hou et al., 2021).

Agricultural waste refers to the waste discharged from agricultural production, agricultural product processing, livestock and poultry breeding, and rural residents. This type of waste accounts for $30 \%$ of the world's total agricultural output
(Salmabanu et al., 2019). In most cases, agricultural waste will be burned or landfilled, causing land pollution and affecting the ecological environment. China is the main producer of bivalve molluscs, with an output of 10.35 million tons in 2010, accounting for $70.8 \%$ of the global bivalve production and $80 \%$ of the global bivalve mollusc aquaculture production. From a chemical point of view, mollusk shells are rich in $\mathrm{CaCO}_{3}$, which accounts for about 


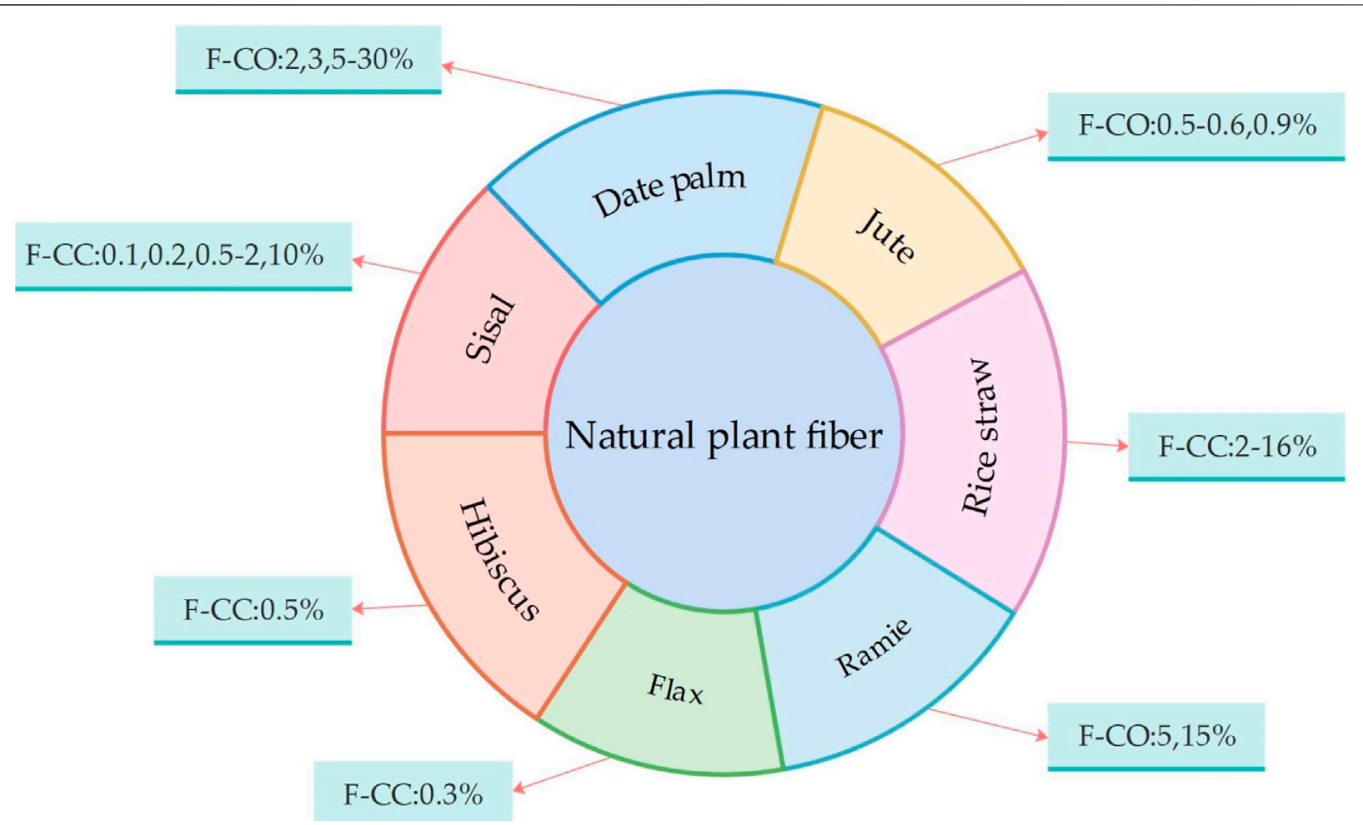

FIGURE 2 | Classification of aquaculture waste in the article.

95\% of their composition (Salmabanu et al., 2019). In order to obtain better quality waste materials, the waste shells need to be properly treated, such as high temperature heating and crushing to obtain the appropriate fineness.

In recent years, the use of agricultural and aquaculture waste as a substitute for concrete ingredients are showing an increasing trend. Compared to the existing reviews, more types of agricultural waste and aquaculture waste should be reviewed, especially from the aspect of utilization ways, besides just waste types.

1) This review classifies agricultural waste into three categories: natural plant fiber, agricultural waste ash, and multiapplication waste (Figure 1A). Among them, natural plant fiber is a material that is original plant in nature and can be directly extracted or applied to concrete production. Agricultural waste ash is the waste produced in the daily agricultural production process, and processed by calcination and other means to form a material with pozzolanic properties. Multi-application waste is the waste remaining in the process of agricultural production or after human consumption, which can be used in concrete research in the form of blocks, sand, and ash.

2) Since generally speaking, aquaculture business is subordinate to agriculture, the aquaculture waste is also reviewed in this paper. Aquaculture wastes (see Figure 1B) refer to different kinds of shells which are easy to obtain in seaside cities and large farms. These shells can also be used as aggregates and ash in concrete preparation.

This paper focuses on the workability, mechanical properties and durability of the concrete prepared by using agricultural and aquaculture wastes. The study on the advantages and disadvantages of these wastes in concrete preparation would provide references for the waste applications and green building materials.

TABLE 1 | Physical properties of natural fibers.

\begin{tabular}{|c|c|c|c|c|c|}
\hline Fiber type & $\begin{array}{l}\text { Fiber length } \\
\qquad(\mathrm{mm})\end{array}$ & $\begin{array}{l}\text { Fiber diameter } \\
\text { (mm) }\end{array}$ & $\begin{array}{l}\text { Tensile strength } \\
\left(\mathrm{N} / \mathrm{mm}^{2}\right)\end{array}$ & Elongation (\%) & References \\
\hline Sisal & $180-600$ & $0.10-0.50$ & $31-221$ & 14.8 & Ramakrishna and Sundararajan (2005b) \\
\hline Date palm & $300-500$ & $0.2-0.8$ & 50 & $9.0-19.4$ & Kriker et al. (2008) \\
\hline Jute & $128-1,525$ & $0.04-0.35$ & $29-312$ & 19.0 & Ramakrishna and Sundararajan (2005b) \\
\hline Hemp & 40 & $0.016-0.05$ & $600-700$ & & Merta and Tschegg (2013) \\
\hline Rice straw & 0.9 & 0.0053 & & & Xie et al. (2015) \\
\hline Ramie & $4-16$ & 0.048 & 500 & 18.2 & Wang (2013) \\
\hline Flax & $10-38$ & & & & Xu (2013) \\
\hline Hibiscus & $163-1,527$ & $0.04-0.16$ & $18-180$ & 12.4 & Ramakrishna and Sundararajan (2005b) \\
\hline
\end{tabular}


TABLE 2 | Usage of natural plant fiber in concrete.

\begin{tabular}{|c|c|c|c|}
\hline Waste products & Usage & $\begin{array}{l}\text { Effect of usage } \\
\text { of waste materials } \\
\text { in concrete }\end{array}$ & References \\
\hline Sisal & Cement & $\begin{array}{l}\text { Plastic and restrained shrinkage reduced } \\
\text { Drying shrinkage increased } \\
\text { Impact resistance improved } \\
\text { Toughness improved }\end{array}$ & $\begin{array}{l}\text { Romildo et al. (2005) } \\
\text { Silva et al. (2010), Romildo et al. (2005) } \\
\text { Ramakrishna and Sundararajan (2005a) } \\
\text { Silva et al. (2010) }\end{array}$ \\
\hline Date palm & Concrete & $\begin{array}{l}\text { Compressive strength decreased } \\
\text { Ductility improved } \\
\text { Density decreased } \\
\text { Thermal conductivity reduced }\end{array}$ & $\begin{array}{l}\text { Kriker et al. (2005), Benmansour et al. (2014) } \\
\text { Kriker et al. (2005) } \\
\text { Benmansour et al. (2014) }\end{array}$ \\
\hline Jute & Concrete & Compressive strength and flexural performance increased & Zhang et al. (2012), (Liu et al. (2013) \\
\hline Hemp & Concrete & Enhancing the fracture energy of concrete & Merta and Tschegg (2013) \\
\hline Rice straw & Cement & $\begin{array}{l}\text { Decrease in bulk density } \\
\text { Increased bending strength } \\
\text { Porosity and water absorption increase with the increase of fiber content } \\
\text { Increased fracture toughness }\end{array}$ & Xie et al. (2015) \\
\hline Ramie & Concrete & After alkali treatment, it can effectively enhance the mechanical properties of concrete & Wang (2013) \\
\hline Flax & Cement & Improve the tensile strength of mortar & $\mathrm{Xu}(2013)$ \\
\hline Hibiscus & Cement & Improve impact resistance of cement mortar & Ramakrishna and Sundararajan (2005b) \\
\hline
\end{tabular}

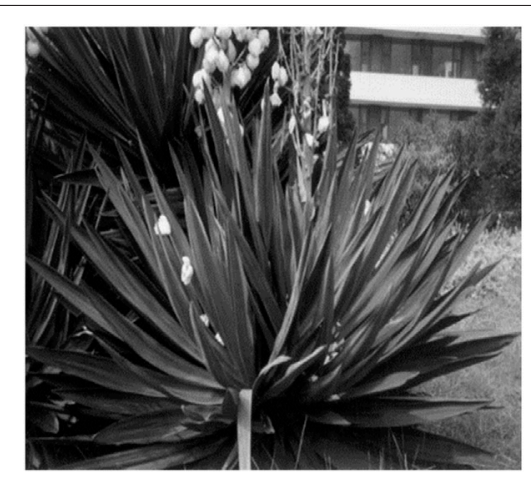

Sisal plant[25]

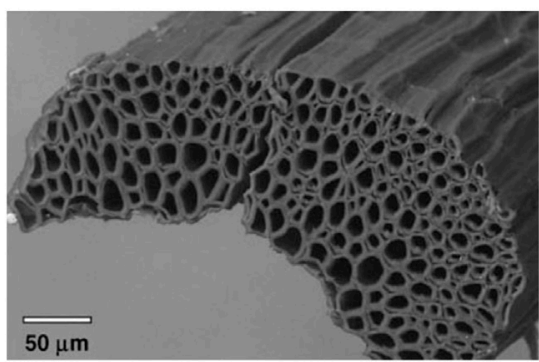

Sisal fiber morphology[10]

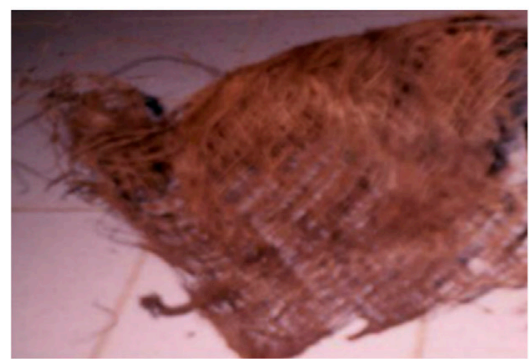

Date palm surface fibers mesh[22]

FIGURE 3 | Substitution and mixing amount of natural plant fiber in concrete in other literatures.

\section{AGRICULTURAL WASTE}

A large number of studies in recent years have shown that agricultural waste can be used as:

1) Supplementary cementitious materials. For example, rice husk and wheat straw husk can be used as pozzolanic materials, which could react with free lime generated by hydration process of clinker silicate, making the cement have a high environmental resistance (Biricik et al., 1999).

2) Used as cement-based reinforced material. For example, Long arranged sisal fibers can be used as reinforcement materials for thin cement-based laminates (Silva et al., 2010) and long bamboo fiber has high durability in cement matrix (Shafigh et al., 2014).

3) Replace part of aggregate. Waste materials such as palm shells and coconut shells can completely or partially replace the role of traditional aggregates in concrete, achieving energy conservation and reducing the pressure of the construction industry on the environment (Pacheco-Torgal and Jalali, 2011).

\section{Natural Plant Fiber}

In recent years, natural plant fiber is widely studied in the manufacture of concrete in order to strengthen the performance of concrete. Natural plant fibers can significantly enhance the toughness and ductility of cement based composites, whilst unfortunately the durability performance in the high alkaline cement matrix raise great concerns (Ramakrishna and Sundararajan, 2005a). In addition, nature plant fibers have the limitations of water swelling and shrink after drying which would comprise the fiber-reinforced effect. The substitution and mixing amount of natural plant fibers in concrete in other literatures are shown in Figure 2. The physical properties of several natural plant fibers are shown in Table 1, and the summary of usage of natural plant fiber in concrete in Table 2. 


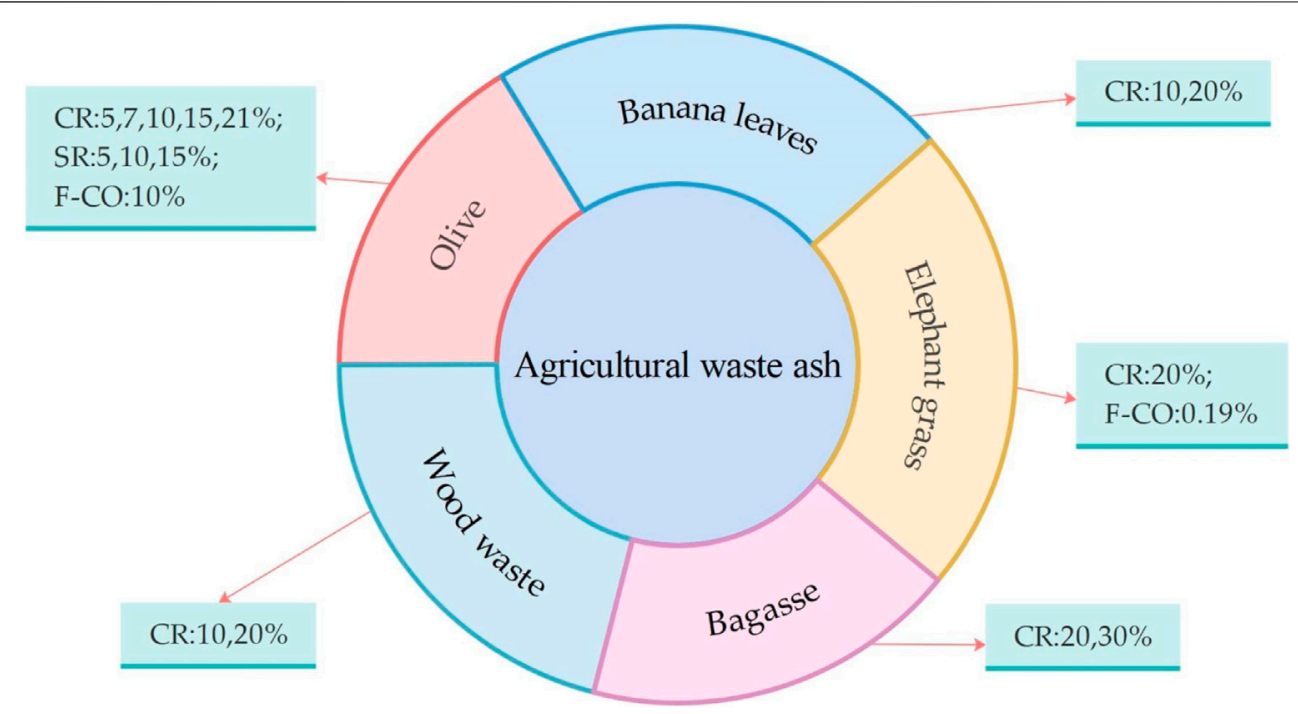

FIGURE 4 | Substitution and mixing amount of agricultural waste ashes in concrete in other literatures.

\section{Sisal Fiber}

Sisal (see Figure 3) is a hard-leaf fiber crop that grows in the tropics. It is the most widely used natural plant hard fiber in the world today. The world's annual production of sisal fiber can reach about 4.5 million tons (Li et al., 2000). For 1 ton of commercially used sisal fibers, 3 ton of residual fibers have been dumped. Sisal fiber has tough texture, wear resistance, salt alkali resistance and corrosion resistance. Sisal fibers under different environmental conditions show better tensile properties than other fibers (Ramakrishna and Sundararajan, 2005a), and has important application value in enhancing the performance of concrete.

Sisal fiber (see Figure 3) is low cost and easy to obtain. The incorporation of sisal fiber can significantly improve the early strength of concrete, since sisal fiber can effectively inhibit the growth of micro cracks (Bao and Meng, 2011). Adding short sisal fiber can also significantly reduce the free plastic shrinkage of cement mortar (Romildo et al., 2005). It should be noted that Sisal fiber is hydrophilic with relatively high porosity as shown in Figure 3, thus it can absorb a large quantity of water, severally weakening their binding with cement matrix. Such fiber-cement interfacial interaction can be enhanced via various strategies. For instance, Yan reported that the surface modification by silane and other coupling agents can change its hydrophilic properties, improving the interfacial properties. The surface roughness of the fiber can be enhanced by permanganate and alkali treatment, thereby increasing the surface area in contact with the matrix. The sisal fiber can be heat treated to improve the bonding performance between the sisal fiber and the matrix and reduce the water absorption rate ( $\mathrm{Li}$ et al., 2000).

The morphology of sisal fiber could also affect its performance in mixed materials. Long-arranged sisal fiber as a thin cementbased laminates material shows potential in semi-structural and structural applications of cement-based materials (Romildo et al., 2005). The shape of sisal fiber has an important influence on the bonding strength and interface properties of cement-based reinforced material (Flávio de et al., 2011).

\section{Date Palm Fiber}

Date palm, which is native to west Asia and north Africa, is one of the most planted palm trees in the world. Date palm trees could provide four types of fibers: leaf fibers in the pedicel, leaf fibers in the stem, wood waste fibers in the trunk and surface fibers around the trunk (Kriker et al., 2005). The surface fiber of date palm has the highest tensile strength in the four types of fibers. The highperformance fiber contained in date palm provides an opportunity for the development of low-cost and highefficiency building materials. The presence of date palm fiber improves the cracking strength, toughness and performance of concrete after cracking (Kriker et al., 2005).

However, the application of these plant fibers in concrete is plagued by durability issues in alkaline environments (Kriker et al., 2008). The surface fibers of date palm trees (see Figure 3) are severely affected by alkaline solution. For example, The surface fibers of date palm trees keep $69 \%$ of the original strength after being placed in the $\mathrm{Ca}(\mathrm{OH})_{2}$ solution for 6 months (Kriker et al., 2008).

The addition of date palm wood fiber can decrease the density of mortar, and improve the thermal insulation performance as well, which plays a huge potential in the research of new building energy-saving bio-composite materials. For example, Benmansour found that adding 5-15\% date palm fiber makes the composite material meet the thermal and mechanical requirements of building materials (Benmansour et al., 2014).

\section{Jute}

Jute is widely cultivated in the area south of the Yangtze river in China. The fiber contained in jute has the characteristics of high tensile strength and low density. At the same time, jute fiber is also one of the lowest cost plant fibers and has good 
TABLE 3 | Usage of agricultural waste ash in concrete.

\begin{tabular}{|c|c|c|c|}
\hline Waste Products (ash) & Usage & $\begin{array}{l}\text { Effect of usage } \\
\text { of waste materials } \\
\text { in concrete }\end{array}$ & References \\
\hline \multirow[t]{3}{*}{ Olive } & Cement & $\begin{array}{l}\text { Residual strength upon exposure to heat increased } \\
\text { Workability reduced } \\
\text { Setting time decreased } \\
\text { Compressive strength decreased } \\
\text { Flexural strength decreased }\end{array}$ & $\begin{array}{l}\text { Al-Akhras et al. (2009) } \\
\text { Al-Akhras and Abdulwahid (2010) }\end{array}$ \\
\hline & Sand & $\begin{array}{l}\text { Workability reduced } \\
\text { Compressive strength increased } \\
\text { Flexural strength increased }\end{array}$ & Al-Akhras and Abdulwahid (2010) \\
\hline & Fiber & $\begin{array}{l}\text { Water demand increased compared to conventional filler } \\
\text { Compressive strength increased compared to conventional filler }\end{array}$ & Cuenca et al. (2013) \\
\hline Banana leaves & Cement & $\begin{array}{l}\text { Compressive strength increased } \\
\text { Tensile strength increased }\end{array}$ & Kanning et al. (2014) \\
\hline \multirow[t]{2}{*}{ Elephant grass } & Cement & $\begin{array}{l}\text { No effect on compressive strength } \\
\text { No effect on MOE } \\
\text { No effect on water absorption }\end{array}$ & Cordeiro and Sales (2015) \\
\hline & Fiber & Minimal increase in fracture energy & Merta and Tschegg (2013) \\
\hline Bagasse & Cement & $\begin{array}{l}\text { Improved mechanical properties } \\
\text { Improve the material's resistance to chloride ion penetration }\end{array}$ & $\begin{array}{l}\text { Ganesan et al. (2007) } \\
\text { Rukzon and Chindaprasirt (2012) }\end{array}$ \\
\hline Wood waste & Cement & $\begin{array}{l}\text { Intensity increases with age } \\
\text { Best compressive strength } \\
\text { Durability is improved } \\
\text { Increased carbonation } \\
\text { Has higher corrosion resistance }\end{array}$ & $\begin{array}{l}\text { Siddique (2012) } \\
\text { Ramos et al. (2013) }\end{array}$ \\
\hline
\end{tabular}

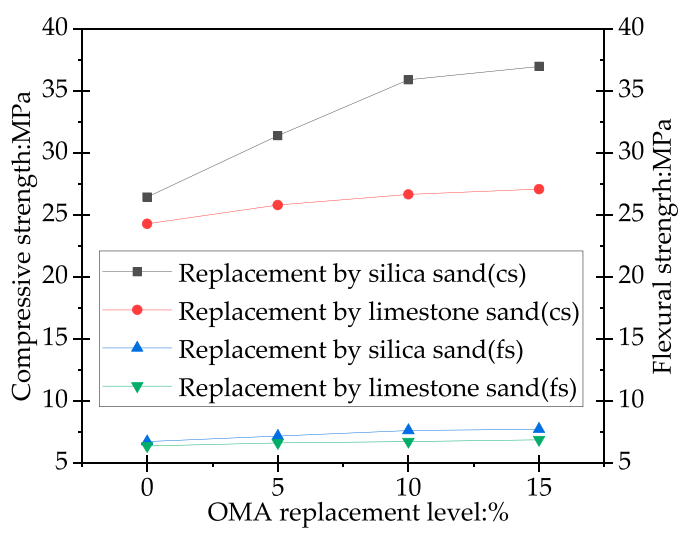

FIGURE 5 | Effect of sand type on the compressive strength and flexural strength of OWA particles (Al-Akhras and Abdulwahid, 2010).

renewable properties. Among various natural plant fibers, jute fiber has a long continuous length. From the perspective of processing technology and availability, jute fiber is an ideal material among natural plant fibers to replace various synthetic fibers for composite reinforcement (Liu et al., 2013).
The incorporation of natural plant fibers has made a great contribution to the improvement of concrete mechanical properties. In particular, compared to other natural plant fibers, jute fiber has a long continuous length, good processing technology, high strength and low elongation characteristics, Jute fiber can effectively enhance the 

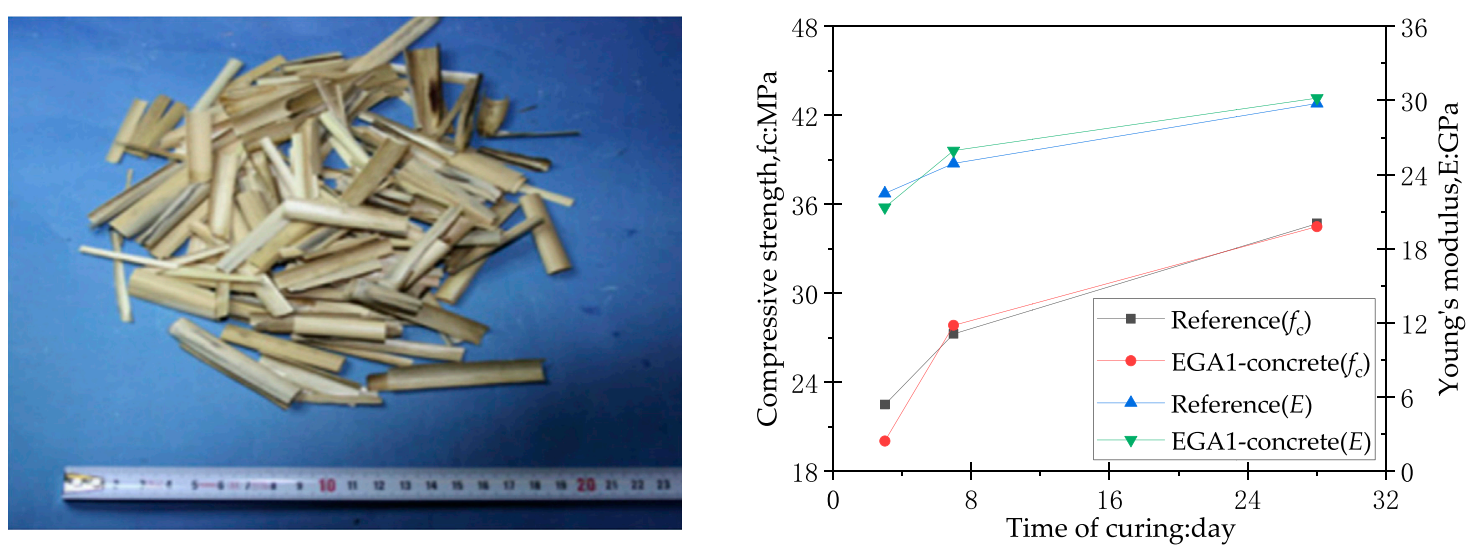

FIGURE 6 | Compressive strength $\left(f_{c}\right)$ and young's modulus $(E)$ of concretes up to 28 days of curing (Merta and Tschegg, 2013; Cordeiro and Sales, 2015).

compressive performance of concrete and has good crack resistance when the dosage is $0.9 \mathrm{~kg} / \mathrm{m}^{3}$ and a certain length (40 $\mathrm{mm}$ in the test) (Zhang et al., 2012). It has been reported that, when the jute fiber content of concrete is $0.5-0.6 \mathrm{~kg} / \mathrm{m}^{3}$, the compressive and flexural strength of the concrete is enhanced most significantly (Liu et al., 2013). However, the length of the mixed fiber in concrete should not be too long (shorter than $40 \mathrm{~mm}$ in the test), otherwise the enhancement effect of the concrete compressive performance will be greatly reduced (Zhang et al., 2012).

In terms of the frost durability of jute fiber concrete, Chen et al. (2015) conducted a freeze-thaw cycle test on jute fiber concrete mixed with different mass ratios and found that the concrete without jute fiber has lower frost resistance than the concrete mixed with jute fiber. When the mass ratio of jute fiber is $0.9 \%$, the mass loss rate and relative mass loss rate of concrete are the minimum.

\section{Others}

Hemp and Flax are the earliest natural plant fibers used by humans which contain rich cellulose and show the characteristics of strong tensile force, good fineness, weak electrical conductivity, fast water absorption and dispersion, and high expansion rate. Merta (Merta and Tschegg, 2013) demonstrated that the fracture energy of hemp fiber reinforced concrete was $70 \%$ higher than that of ordinary concrete. Zhang (Zhang, 2011) used a mixture of loose flax, bentonite, and cement to successfully solve the problem of slurry leakage in the cofferdam impervious wall of Jin'anqiao hydropower Station. Adding flax fiber to ordinary cement mortar can effectively reduce the cracking caused by restrictive plastic shrinkage resulting from its good hydrophilic properties $(\mathrm{Xu}, 2013)$. In addition, ramie also known as "Chinese grass" by the world, is one of the important fiber crops in ancient China. The alkali-treated ramie fiber can effectively enhance the mechanical properties of concrete and prevent cracking when the content reaches a certain amount (Wang, 2013).
Besides hemp plant, rice straw from the wastes left after rice used is also a good source of natural fiber. Compared with fiber-free composite materials, the mechanical properties of rice straw fiber reinforced cement-based composite materials have been significantly improved. The addition of rice straw fibers reduces the bulk density of the composite material by $12.4-37.3 \%$ and increases the bending strength by $24.3 \%$ (Xie et al., 2015). As a very common shrub flower species in Asia, hibiscus could also provide rich natural fiber to reinforce cement-based composite materials. Researchers (Ramakrishna and Sundararajan, 2005a) found that the addition of $2.5 \%$ hibiscus fiber by weight of cement can improve the impact resistance of cement mortar. The hibiscus fiber can maintain $0 \%, 10-20 \%$, and $20 \%$ of the original strength after alternating dry and wet in saturated lime, $\mathrm{NaOH}$ and fresh water for 60 days (Ramakrishna and Sundararajan, 2005b).

\section{Agricultural Waste Ash}

Agricultural waste ash refers to the ash material produced by the calcination method. Most agricultural waste ash has the characteristics of volcanic ash, and can be used as the pozzolan material in mortar and concrete to achieve the expected effect, and in addition to improve the performance of mortar and concrete. The substitution and mixing amount of agricultural waste ash in concrete in other literatures are shown in Figure 4. The usage of agricultural waste ash in concrete is summarized in Table 3.

\section{Olive Waste Ash}

Olive waste contains olive pulp, peel and residual oil. Approximately 3 ton of pruning residues are generated each year from 1 ha of olive trees, most of which are disposed inconsiderately. Olive ash containing about $22 \% \mathrm{SiO}_{2}$ and $42 \%$ lime can be produced by burning large amounts of olive waste, and it is a new type of auxiliary cementing material (Al-Akhras and Abdulwahid, 2010). 
TABLE 4 | Alternative application of multi-application waste.

\begin{tabular}{|c|c|c|c|}
\hline \multirow[t]{2}{*}{ Multi-application waste } & \multicolumn{3}{|c|}{ Substitution } \\
\hline & Aggregate & Pozzolanic material & Fiber material \\
\hline Bamboo & & $\sqrt{ }$ & $\sqrt{ }$ \\
\hline Straw & $\sqrt{ }$ & $\sqrt{ }$ & $\sqrt{ }$ \\
\hline Rice husk & $\sqrt{ }$ & $\sqrt{ }$ & \\
\hline Corn & $\sqrt{ }$ & $\sqrt{ }$ & $\sqrt{ }$ \\
\hline Coconut shell & $\sqrt{ }$ & & $\sqrt{ }$ \\
\hline Palm shell & $\sqrt{ }$ & $\sqrt{ }$ & \\
\hline Rubber & $\sqrt{ }$ & & $\sqrt{ }$ \\
\hline
\end{tabular}

In the production of concrete, although olive ash exerts good compaction performance and improves the compressive strength of concrete, it requires relatively high water consumption. Therefore, it is necessary to add additives to control its high water absorption (Cuenca et al., 2013). At the same time, the high-temperature performance of the concrete mixed with olive ash is better than that of ordinary concrete. In addition the excellent high-temperature resistance of olive ash makes it have the potential to be a thermal insulation material (Al-Akhras et al., 2009).

Incorporating olive ash material into cementitious mortar can improve the performance of the cementitious mortar, since it helps reduce the porosity of the bonding interface. As a partial replacement of sand, the compressive and flexural strength of mortar increase with the increase of olive ash content (see Figure 5) (Al-Akhras and Abdulwahid, 2010). However, as a partial replacement of cement, the compressive and flexural strength of mortar will be decreased with the increase of olive ash content, since the amount of cementitious materials is reduced. In addition, compared with autoclaved curing, wet-cured olive mortar exhibits better compressive and flexural strength.

\section{Banana Leaf Ash}

Bananas with extremely large leaves are mostly grown in tropical and subtropical regions. According to statistics, in 2012, banana plants produced approximately 10 million tons of banana leaf ash (Salmabanu et al., 2019). Banana leaves must be properly burned in open air at the temperature about $900^{\circ} \mathrm{C}$ for $24 \mathrm{~h}$ to obtain high-performance banana leaf ash (Kanning et al., 2014). According to reports, the burned banana leaf ash has high pozzolanic activity after being grinded for at least 30 min (Kanning et al., 2011).

As a pozzolan material, banana leaf ash can effectively improve the mechanical properties of the mortar. Kanning et al. (2014) used an artificial aging test box to evaluate the mechanical and chemical properties of concrete mixed with 10 and $20 \%$ banana leaf ash. The results show that the compressive strength and average tensile stress of the mixture with $10 \%$ banana leaf ash are nearly 25 and $10 \%$ respectively higher than those of other concrete without banana leaf ash. The compressive strength and average tensile strength of the concrete containing $20 \%$ banana leaf ash are 12 and $20 \%$ respectively higher than those of the concrete without banana leaf ash.

\section{Elephant Grass Ash}

As a tropical grass native in Africa, elephant grass (see Figure 6) requires very little nutrients and water to grow, but can produce large amounts of ash after burning and grinding. Since, elephant grass contains a large amount of amorphous $\mathrm{SiO}_{2}$, this ash has great potential to become a pozzolan material.

The control of combustion parameters, such as temperature, heating rate and soaking time are the main factors that determine the amount and structural state of $\mathrm{SiO}_{2}$ in elephant grass. Cordeiro and Sales (2015) found that the pretreatment of metal oxide leaching method can increase the content of silicon oxide and reduce the burning loss of elephant grass ash. Within 28 days of curing, the use of $20 \%$ elephant grass ash cement substitutes would not change the compressive strength of $35 \mathrm{MPa}$ concrete (see Figure 6). Nakanishi et al. (2014) used elephant grass materials from different origins (Napier and Cameroon) to produce elephant grass ash after being calcined at $700^{\circ} \mathrm{C}$.

\section{Bagasse Ash}

Bagasse ash burned after sugar production at a certain temperature is a promising pozzolanic material that can be used as an auxiliary material for Portland cement in mortar and concrete (Aprianti et al., 2015). The $\mathrm{SiO}_{2}$ in the bagasse ash forms a new hydration product-calcium $\mathrm{SiO}_{2}$ during the hydration reaction with cement, which improves the performance of concrete.

From the comprehensive experiment conducted by Ganesan et al. (2007), when the cement replacement rate of bagasse ash is $20 \%$, the improvement on the compressive strength, split tensile strength, water absorption, permeability, chloride ion diffusion and resistance to chloride ion permeability of the concrete has achieved the most ideal effect. On the contrary, Rukzon and Chindaprasirt (Rukzon and Chindaprasirt, 2012) proposed that when the mixed amount of bagasse ash is $30 \%$, the material's resistance to chloride ion penetration can be further improved. The incorporation of bagasse ash increases the pozzolan hydration reaction and the generation of hydration products which reduces the $\mathrm{Ca}(\mathrm{OH})_{2}$ in the concrete, and significantly improves the concrete's resistance to chloride ion penetration. In addition, the particles of bagasse ash are finer than Portland cement, and the surface area of the reaction is increased while the water absorption is increased. 
TABLE 5 | Usage of multi-application waste in concrete.

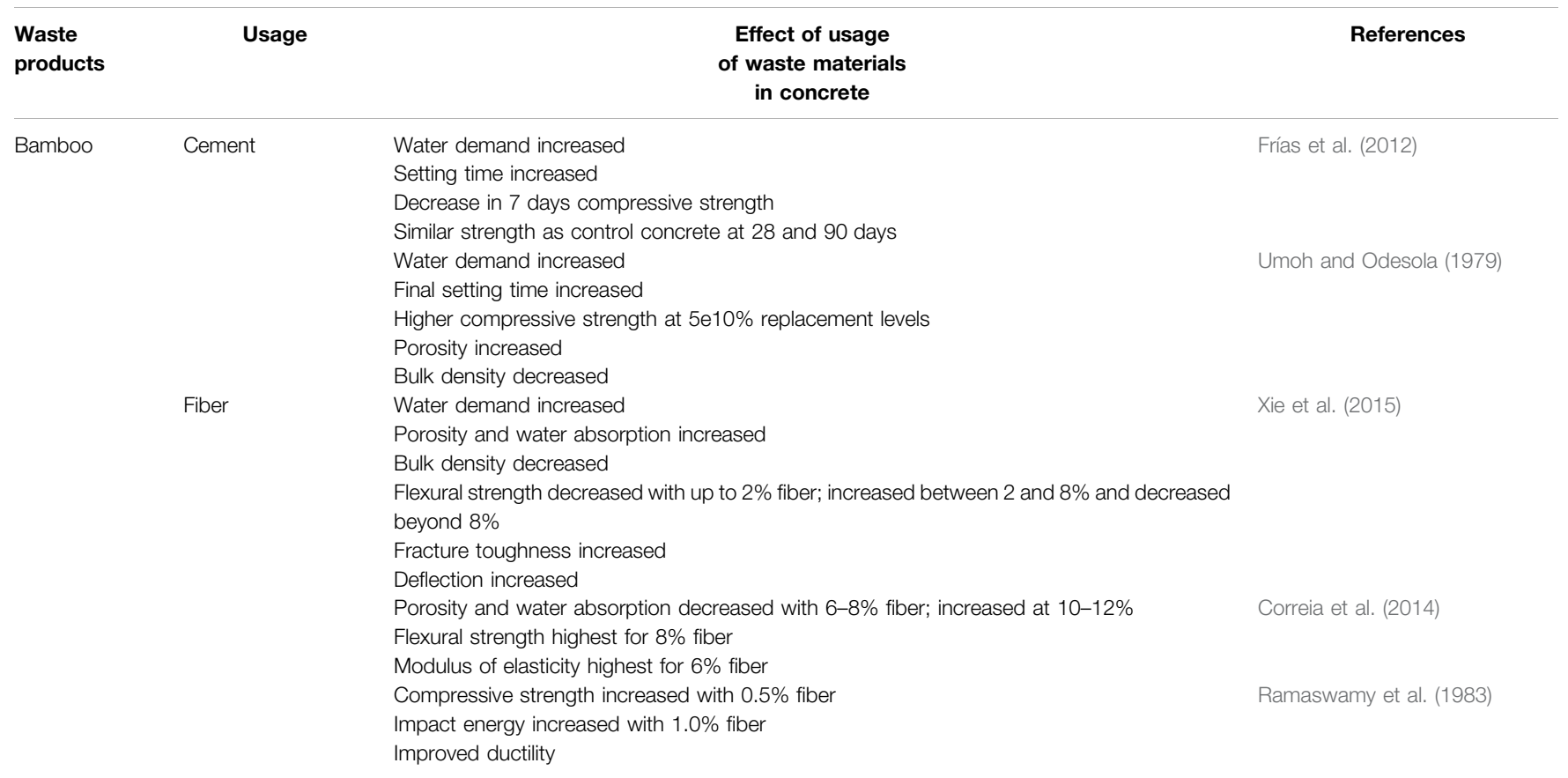

\begin{tabular}{|c|c|c|c|}
\hline \multirow[t]{11}{*}{ Wheat straw } & Cement & $\begin{array}{l}28 \text { days compressive strength decreased; similar } 180 \text { days strength as control for } 8 \% \\
\text { replacement level } \\
\text { Flexural strength increased } \\
\text { Improved resistance to sulfate attack in terms of compressive strength }\end{array}$ & Biricik et al. (2000) \\
\hline & & Durability towards freeze-thaw damage improved & Al-Akhras (2011) \\
\hline & Sand & Flow decreased & Al-Akhras and Abu-Alfoul (2002) \\
\hline & & Initial setting time increased & \\
\hline & & Compressive, splitting tensile and flexural strengths increased & \\
\hline & & Thermal cycling resistance improved & Al-Akhras et al. (2008) \\
\hline & & Compressive strength increased & Binici et al. (2008) \\
\hline & & Sulfate resistance improved & \\
\hline & & Abrasion resistance improved & \\
\hline & & Water penetration depth reduced & \\
\hline & Fiber & Minimal increase in fracture energy & Merta and Tschegg (2013) \\
\hline \multirow[t]{4}{*}{ Rice husk } & Cement & Effectively resist damage during freeze-thaw cycles & Zhang (2015) \\
\hline & & Improved resistance to chloride ion penetration & \\
\hline & & $\begin{array}{l}\text { Enhanced resistance to acid corrosion } \\
\text { Both initial setting and final setting time of cement are prolonged }\end{array}$ & Wang et al (2017) \\
\hline & Sand & $\begin{array}{l}\text { Can be used as a mixed material of structural lightweight concrete and thermal insulation } \\
\text { concrete to achieve insulation }\end{array}$ & Shafigh et al. (2014) \\
\hline
\end{tabular}

\begin{tabular}{|c|c|c|c|}
\hline \multirow[t]{7}{*}{ Corncob } & Cement & $\begin{array}{l}\text { Workability reduced } \\
\text { Early strength decreased } \\
\text { Strength gain increased }\end{array}$ & Adesanya and Raheem (2009a) \\
\hline & & Initial and final setting times increased & Adesanya and Raheem (2009b) \\
\hline & Sand & Compressive strength increased & Binici et al. (2008) \\
\hline & & Sulfate resistance improved & \\
\hline & & Abrasion resistance improved & \\
\hline & & Water penetration depth reduced & \\
\hline & Coarse aggregate & Comparable thermal properties with expanded clay lightweight concrete & Pinto et al. (2012) \\
\hline \multirow[t]{2}{*}{ Coconut shell } & Coarse aggregate & Reduce large deflection of plastic shrinkage cracks & Gunasekaran et al. (2014) \\
\hline & Fiber & The initial strength retention rate is higher than other fibers & $\begin{array}{l}\text { Ramakrishna and Sundararajan } \\
\text { (2005a) }\end{array}$ \\
\hline \multirow[t]{3}{*}{ Palm shell } & Coarse aggregate & Improved elastic modulus and toughness modulus & Ahmmad et al. (2014) \\
\hline & & Higher ductility and aggregation interlocking characteristics & Alengaram et al. (2013) \\
\hline & Cement & Improve the hardening performance and durability of concrete & Safiuddin et al. (2011) \\
\hline Rubber & Coarse aggregate & Compressive strength is suitable & Muthusamy et al. (2014) \\
\hline
\end{tabular}




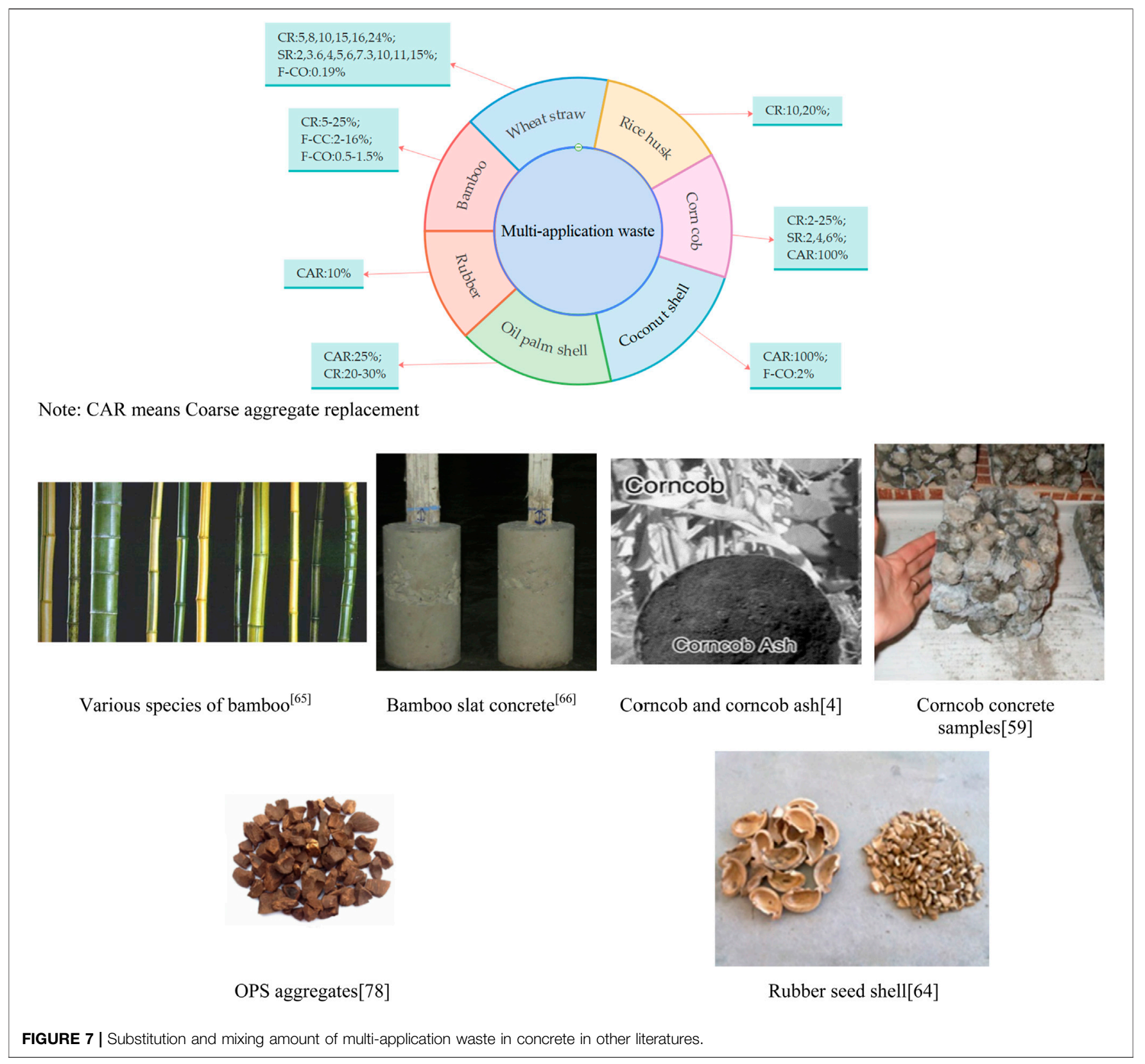

The difference in the results of these studies may result from the different craft and material selection for the production of bagasse ash. However, it can be proved that the incorporation of bagasse ash can significantly improve the performance of concrete.

\section{Wood Waste Ash}

The residue produced by burning wood waste such as sawdust, sawdust, and bark is called wood waste ash. Burning wood waste will produce an average of $6-10 \%$ wood waste ash (Siddique, 2012). According to reports, about $70 \%$ of wood waste ash is landfilled, $20 \%$ is used as a soil supplement, and the remaining $10 \%$ is used for other purposes including construction materials, metal recycling and pollution control (Siddique, 2012). As a building material, the sum of three oxides $\mathrm{SiO}_{2}, \mathrm{Al}_{2} \mathrm{O}_{3}$, and $\mathrm{Fe}_{2} \mathrm{O}_{3}$ in wood waste ash exceeds the minimum limit of fly ash. In addition, the chloride contained in wood waste ash is far below the required standard, and the other obtained parameters are almost all conducive to the performance of coagulation (Ramos et al., 2013).

The physical and chemical properties of wood waste ash will be affected by factors such as tree species, origin, and burning method. In terms of concrete performance, the partial replacement of cement by wood waste ash would adversely affect concrete slump. As the content of wood waste ash increases, the water absorption capacity of concrete increases, but the strength of concrete decreases slightly. It was reported that 


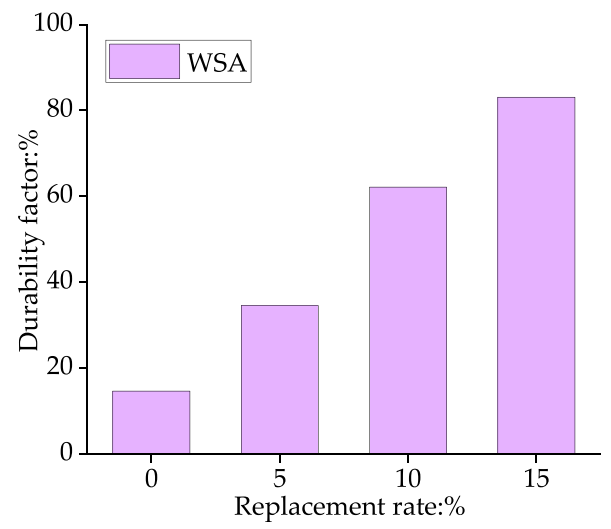

FIGURE 8| Effect of WSA content on the durability factor of concrete (AIAkhras, 2011)

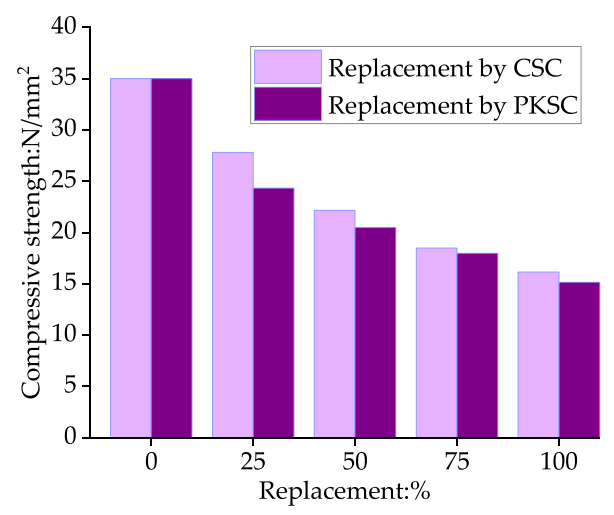

FIGURE 9 | Comparison compressive strength of CSC and PKSC of mix proportion 1:1:2 at 28 days curing (Olanipekim et al., 2006).

the concrete can reach the ideal state, when $20 \%$ of cement is replaced by wood waste ash (Siddique, 2012).

Wood waste ash could be used as part of the cement substitute material in mortar. The compressive strength decreases with the increase of wood waste ash content, but it increases with the extension of the curing time (Ramos et al., 2013). The carbonization depth of wood waste ash cement mixture is greater than that of Portland cement mixture, and the carbonization effect increases with the increase of wood waste ash content. This may be due to $\mathrm{CH}$ reduction and consequent pH reduction (Carević et al., 2019; Carević et al., 2021).

In addition, wood waste ash can effectively inhibit the harmful expansion caused by the alkali-silicon reaction whilst the increasing content of wood waste ash can reduce the expansion rate. However, due to delayed hydration of free and dead-burned $\mathrm{CaO}$ and $\mathrm{MgO}$, the ash content greater than or equal to $20 \%$ will lead to severe swelling (Ukrainczyk et al., 2016). Compared with ordinary concrete, the concrete containing wood waste ash has higher corrosion resistance when exposed to monoacid solution. When the concrete is under dibasic acid solution corrosion, the situation is just the opposite. The mineral admixture mixed with $20 \%$ wood waste ash and $80 \%$ fly ash can significantly improve the chloride ion diffusion resistance of concrete at the level of $25 \%$ cement substitution (Cheah and Ramli, 2011).

\section{Multi-Application Waste}

Multi-application waste material can be interpreted as the waste remaining in the process of agricultural production or human consumption, which can be reused in the form of lumps, sand, ash, fiber etc. in mortar and concrete production. The summary of multi-application waste is shown in Table 4. The detailed usage and mixing amount of multi-application waste in mortar and concrete is shown in Table 5 and Figure 7.

\section{Bamboo}

The annual production of bamboos all over the world is about 20 million ton, mainly in Asia and Latin America. Bamboo (see Figure 7) with the advantages of good mechanical properties, high flexibility, fast growth, light weight, and low purchase cost, is a promising building material (van der Lugt et al., 2006).

In the 1980s, Ramaswamy et al. (1983) verified the possibility of bamboo fiber blending into concrete. Compared with ordinary concrete, the impact strength of bamboo fiber concrete is effectively improved and the shrinkage characteristics are significantly reduced. Xie et al. (2015) produced a cement paste mixed with bamboo fiber for performance tests. With the increase of time, the accumulation of $\mathrm{Ca}(\mathrm{OH})_{2}$ on the surface of the bamboo fiber is increased, which significantly reduces the fracture performance of the composite material. The bamboo fiber concrete shows a sufficiently high stability and the optimal fiber content is $16 \%$.

Bamboo leaves can be calcined at $600^{\circ} \mathrm{C}$ to make bamboo leaf ash, which contains $78.7 \%$ of $\mathrm{SiO}_{2}$. Tested by the volcanic ash activation method, bamboo leaf ash is a highly active volcanic ash (Frías et al., 2012). Bamboo leaves activated at $600^{\circ} \mathrm{C}$ and controlled holding time of $1.2 \mathrm{~h}$ can prepare a pozzolan suitable for the future production of type II/A cement (Frías et al., 2012). With the increase of bamboo leaf ash content, the demand for water in the mixture increased. As the curing age increases, the increase of bamboo leaf ash content would increase the compressive strength, porosity and water absorption, but decrease the bulk density of the cementitious mortar (Umoh and Odesola, 1979).

Bamboo also has the potential to replace steel bars to reinforce concrete structures. Through a series of performance tests, the bamboo slat concrete (see Figure 7) shows good performance. Treating bamboo as a reinforcement material, the bearing capacity of the beam could also be significantly improved (Agarwal et al., 2014).

\section{Straw}

Straw containing the properties of volcanic ash is a multi-purpose renewable biological resource. In addition, most straws are rich in 

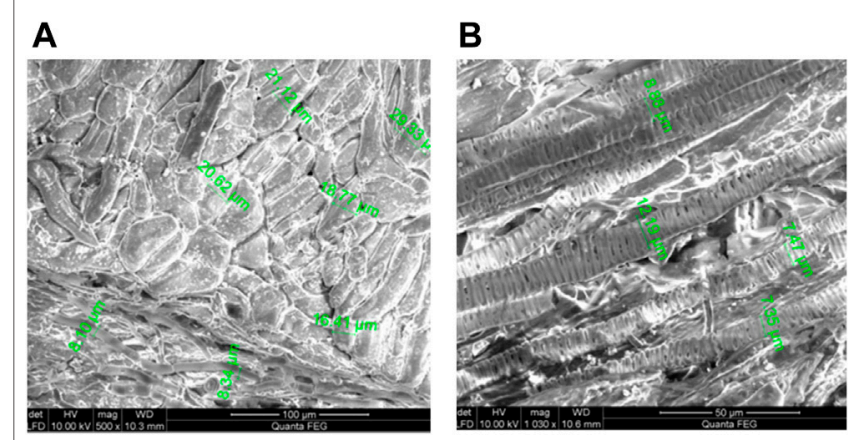

FIGURE 10 |SEM images on CS specimens (Gunasekaran et al., 2012).

(A) Discrete cells of CS; (B) Continuous cells of CS.

crude fibers that could be used to improve the performance of concrete.

\section{Wheat Straw}

It is estimated that out of the world's annual cereal production of 880 million ton, 550 million ton is wheat straw. The content of $\mathrm{SiO}_{2}$ in the ash of wheat straw after incineration is about $73 \%$, indicating the pozzolanic properties. The wheat straw ash produced by burning wheat straw at $670^{\circ} \mathrm{C}$ has better pozzolanic activity than that by burning at $570^{\circ} \mathrm{C}$ (Biricik et al., 1999). Under the autoclave treatment with the increase of the wheat straw ash content, the mechanical properties of the mortar are steadily improved (Al-Akhras and Abu-Alfoul, 2002).

Incorporating wheat straw ash into concrete as a partial replacement of ordinary cement can improve the durability of concrete against the deterioration of freeze-thaw cycles as shown in Figure 8 (Al-Akhras, 2011). In contrast, when the concrete is exposed to thermal cycling, its compressive strength will be significantly reduced (Al-Akhras et al., 2008). The thermal cycle at $30-150^{\circ} \mathrm{C}$ will cause many cracks in the wheat straw ash concrete specimens. The increase of thermal cycles would increase the maximum width and strength of the cracks and the reduction in compressive strength of wheat straw ash concrete. With the increase of wheat straw ash content, the thermal cycle resistance of wheat straw ash concrete is also improved (AlAkhras et al., 2008).

Concrete made of wood waste chips, barley straw, and sand is a kind of concrete that is both thermally insulating and loadbearing which can be used for exterior walls in arid environments or other components (Belhadj et al., 2014). Due to the mixing of barley straw and wood waste chips, the problem of concrete shrinkage could be solved. The gel produced by the pozzolanic reaction is more susceptible to erosion by $\mathrm{MgSO}_{4}$. Mixing wheat straw ash generally increases the strength of mortar at $\mathrm{MgSO}_{4}$ solution whilst the substitution of wheat straw ash has a beneficial effect on the compressive strength of the mortar (Biricik et al., 2000).

\section{Rape Straw}

Rape straw has high crude fiber content and the fibrous structure of the wood part resulting in the characteristics of hard surface texture, fine microstructure, high tensile strength and good toughness. The thermal conductivity of rape straw fiber is much lower than that of other fibers. After adding rape straw fiber into concrete, the thermal conductivity of the concrete specimens is significantly decreased. This decrease becomes even severer with the increase of the rape straw fiber (Zeng et al., 2018).

\section{Rice Husk}

Rice husk ash by burning rice husk which not only is low cost, but also has good pozzolanic effect and micro-aggregate effect, can be used to improve the strength and durability of cement matrix and concrete (Zheng et al., 2018).

With the increase of rice husk ash content, the initial setting and final setting time of the cement mixture are prolonged. When rice husk ash is ground for $45 \mathrm{~min}$ and the content is $10 \%$, the setting time of the mixture is close to that of cement (Wang et al., 2017).

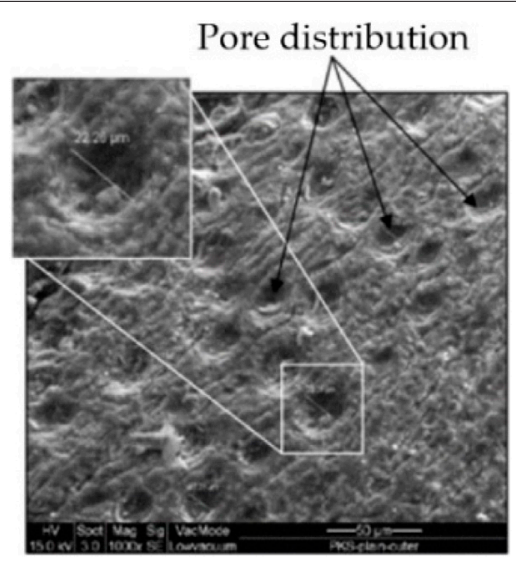

FIGURE 11 | Micro-pores on outer surface (Alengaram et al., 2011). 


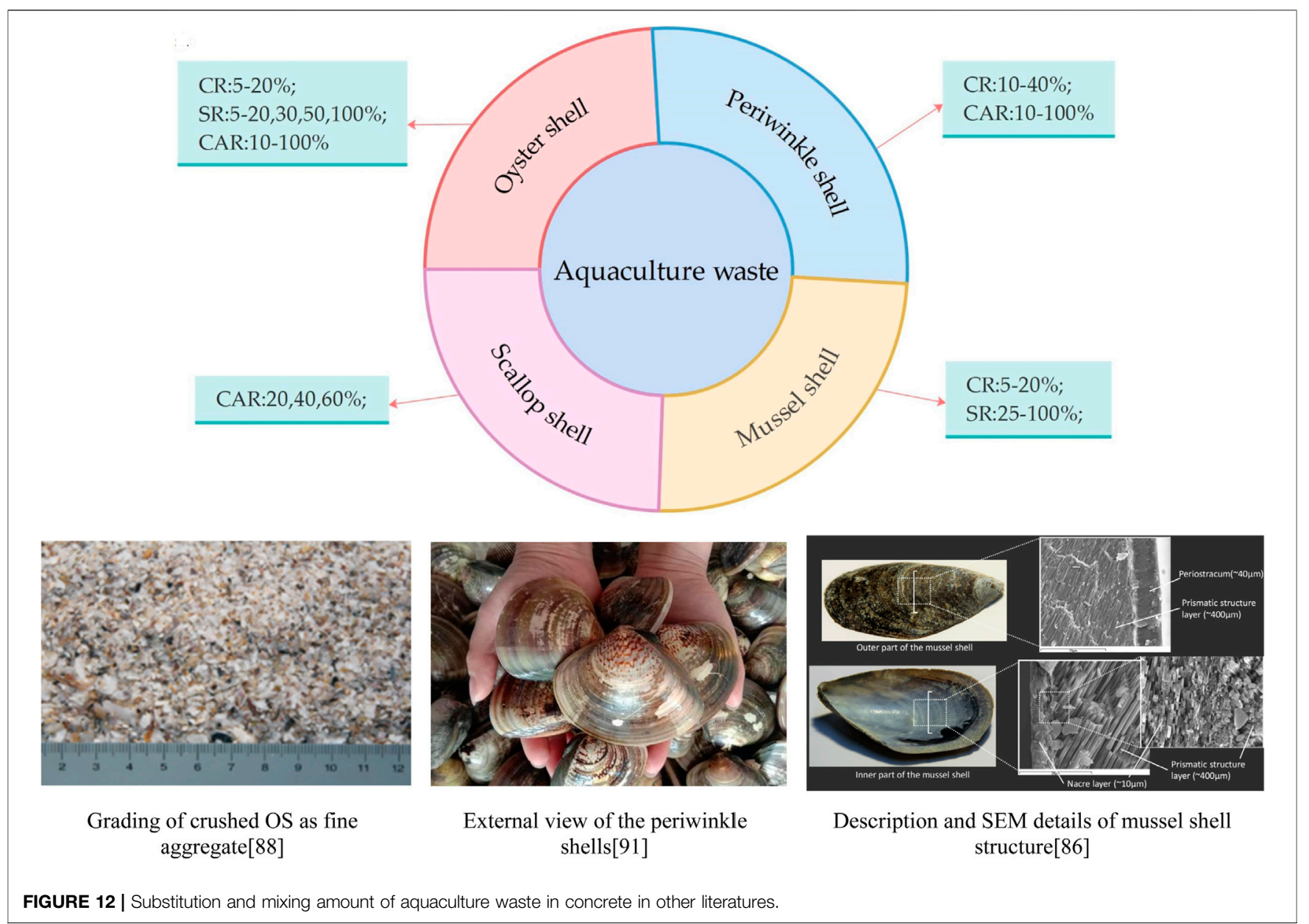

For concrete, the addition of rice husk ash can significantly improve the internal structure of concrete and make it more compact, thereby enhancing the mechanical properties, frost resistance, chloride ion penetration resistance and acid erosion resistance of rice husk ash concrete (Zhang, 2015). In terms of mechanical properties, rice husk ash fine particles can fill the internal pores of concrete, whilst the rice husk ash contains reactive amorphous $\mathrm{SiO}_{2}$, which will react with $\mathrm{Ca}(\mathrm{OH})_{2}$ generated after cement hydration to increase the strength of concrete. This activity is mainly reflected in the later stage of cement hydration (Wang et al., 2017). When the mixing amount of rice husk ash reaches $20 \%$, the reinforcement effect of rice husk ash on concrete is the strongest (Zhang, 2015).

In terms of durability, the concrete mixed with rice husk ash can effectively resist damage during freeze-thaw cycles, and the relative dynamic elastic modulus can be basically guaranteed to be greater than $60 \%$ at 200 freeze-thaw cycles (Zhang, 2015). Rice husk ash fills the gap among cement particles and fly ash particles, increasing the density between the powders, and improving the resistance to chloride ion penetration of concrete (Wang et al., 2017). When the concrete mixed with $20 \%$ rice husk ash, the antichloride ion penetration performance of the concrete is exerted to the best (Zhang, 2015). Mixing rice husk ash can also effectively enhance the acid resistance of concrete, whose compressive strength loss rate, mass loss rate and thickness loss rate are all lower than the ordinary concrete specimens. Similarly, when the rice husk ash content is $20 \%$, the resistance to acid erosion of concrete is the best (Zhang, 2015).

In addition, rice husk could also be used to replace natural fine and coarse aggregates in the mixture of structural lightweight concrete and heat-insulating concrete to achieve the purpose of insulation (Shafigh et al., 2014).

\section{Corncob}

Corncob has the characteristics of uniform organization, suitable hardness, good toughness, strong water absorption and good wear resistance. Corncob ash by burning corncob under certain conditions exerts good pozzolanic properties (see Figure 7) whose content of $\mathrm{SiO}_{2}$ is more than $65 \%$ (Shafigh et al., 2014).

As the content of corncob ash increases, the $\mathrm{SiO}_{2}$ content in the mixture increases at the same time, therefore corncob ash concrete needs more water to make the mixture workable (Adesanya and Raheem, 2009a). In addition, as the content of corncob ash increases, the stability and setting time of cement increase, since the increase of corncob ash reduces the surface area of Portland cement, hinders the hydration process, and 
adversely affects the combination of Portland cement (Adesanya and Raheem, 2009b).

With the increase of corncob ash content, $\mathrm{more}^{\mathrm{SiO}_{2}}$ can react with the lime produced during cement hydration, thereby producing more cementitious material, which helps to improve the compressive strength of the concrete (Adesanya and Raheem, 2009a). The best blending amount of corncob ash in concrete is $8 \%$, and more than $10 \%$ may not be conducive to the development of concrete compressive strength, and the best curing time is 120 days (Augustine and Tiza, 2016). The specimens mixed with $6 \%$ corncob ash wear more slowly than other specimens, so is the sulfate resistance (Binici et al., 2008). This may be due to the formation of a good interface between the ash and the agglomerated matrix.

At the same time, corncob particles also have great potential as aggregates for lightweight concrete. Pinto et al. (2012) found that corncob concrete (see Figure 7) prepared with a ratio of 6:1:1 (corncob particles: Portland cement: water) shows acceptable mechanical properties. Compared corncob concrete with the concrete made of expanded clay, the density and thermal characteristics of corncob concrete are consistent with those of expanded clay concrete, except for the compressive strength. This may be related to the corncob particle size, component ratio and curing time. At present, corncob concrete is only suitable for nonstructural applications, and further research is needed on how to improve the strength of corncob concrete.

\section{Coconut Shell}

Coconut shell is one of the most promising agricultural wastes and can be used as coarse aggregate in concrete production. Compared with palm shell (PKSC), the compressive strength of coconut shell concrete (CSC) is higher (see Figure 9). From an economic point of view, coconut shell is also more suitable as a substitute for concrete aggregate than palm shell (Olanipekim et al., 2006).

Theoretically speaking, coconut shells can replace natural coarse aggregates to improve the compressive strength of concrete. However, due to the shape, rough texture and excessive density of coconut shell, the strength of coconut shell concrete is difficult to exert. Therefore, the appropriate amount of coconut shell can be used to prepare workable concrete with good strength (Tomas and Ganiron, 2013).

Compared with ordinary concrete, coconut shell concrete has higher ductility and almost the same crack width under the initial cracking torque with corresponding reinforcement ratio (Gunasekaran et al., 2013a). The flexural performance of coconut shell concrete is comparable to other lightweight concretes. Under normal conditions of use, the deflection and cracking characteristics of coconut shell concrete are equivalent to those of ordinary concrete (Gunasekaran et al., 2013b). At the same time, under the scanning electron microscope, the pore structure in the coconut shell (see Figure 10) appeared as a reservoir (Gunasekaran et al., 2014). Due to aging, the cracks tend to shrink, indicating that the cohesiveness between coconut shell and cement paste is good (Gunasekaran et al., 2012). Coconut shell aggregate concrete under intermittent curing has the highest strength, followed by full water curing, and air-dried curing.

Research shows that fly ash partially replacing cement, coconut shell replacing coarse aggregate, and cullet glass sand replacing fine aggregate could be used to make economical and environmentally friendly concrete which could be used for lightweight structures (Phatak et al., 2014). Even though coconut shells show good mechanical properties in concrete, it is still necessary to conduct sufficient research on coconut shell concrete before practical application, especially in terms of durability (Reddy et al., 2014). Besides, the fiber extracted from coconut shell can be used in mixing cementitious mortar. The initial strength retention rate of coconut shell fiber is higher than other fibers after exposure to different media for a certain period of time.

\section{Palm Shell}

Palm shell (see Figure 7) is discarded during the extraction of palm fruit (Olanipekim et al., 2006). Annually 4 million tons of oil palm shell produced by Malaysia which is expected to rise further by the year 2020. Since 1984, a lot of research has been carried out on palm shell as a lightweight aggregate. As aggregate, palm shell has very good wear resistance, which is about $80 \%$ lower than traditional coarse aggregates. In addition, the impact value and crush value of palm shell are low, indicating its high shock absorption capacity (Shafigh et al., 2014). Under scanning electron microscopy, it can be seen that there are a large number of micro-pores with a size of $16-24 \mu \mathrm{m}$ on the outer surface of palm shell (see Figure 11).

For palm shell concrete, the different curing conditions will also affect the compressive strength of palm shell concrete. According to reports, the ideal curing condition is full water curing (Shafigh et al., 2011b). Under full water curing conditions, it can produce palm shell high-strength lightweight concrete with a 28 days compressive strength about $43-48 \mathrm{MPa}$ and a dry density about $1870-1990 \mathrm{~kg} / \mathrm{m}^{3}$. Palm shell high-strength lightweight concrete is very sensitive to insufficient curing, so at least 7 days of wet curing is required (Shafigh et al., 2011b). When reducing the water-cement ratio, increasing the palm hull content or reducing the cement content, the sensitivity of palm hull concrete under insufficient curing conditions can also be reduced (Shafigh et al., 2012a). Under all curing conditions, the compressive strength of palm shell concrete increases with age, but it is still lower than that of ordinary concrete. In general, the compressive strength of palm shell concrete is $49-55 \%$ lower than that of ordinary concrete (Mannan and Ganapathy, 2004) resulting from the smooth surface of the shell which will cause poor bonding between the palm shell and the cement matrix (Shafigh et al., 2012b). On the positive side, compared with ordinary concrete, palm shell concrete also has higher ductility and polymer interlocking properties (Alengaram et al., 2013). The ductility index of palm shell concrete is 2.8 times higher than that of ordinary concrete (Ahmmad et al., 2014). Therefore, palm shell lightweight concrete is more suitable for the application of structural seismic performance than ordinary lightweight concrete. To improve the bonding force between palm shell 
TABLE 6 | Influence of aquaculture waste on the mechanical properties of concrete.

\begin{tabular}{|c|c|c|c|c|c|}
\hline \multirow{2}{*}{$\begin{array}{l}\text { Aquaculture } \\
\text { waste }\end{array}$} & \multicolumn{4}{|c|}{ Concrete mechanical properties } & \multirow[t]{2}{*}{ References } \\
\hline & Compressive strength & $\begin{array}{l}\text { Flexural } \\
\text { strength }\end{array}$ & $\begin{array}{l}\text { Elastic } \\
\text { modulus }\end{array}$ & Shrinkage strain & \\
\hline Oyster shell & $\begin{array}{l}\text { No obvious effect in the early stage; } \\
\text { long-term effect }\end{array}$ & - & $\begin{array}{l}\text { Obvious } \\
\text { impact }\end{array}$ & $\begin{array}{l}\text { Increase in content; increase } \\
\text { shrinkage Strain }\end{array}$ & $\begin{array}{l}\text { Yang et al. (2005), Yang et al. (2010), Eo } \\
\text { and Yi (2015) }\end{array}$ \\
\hline Periwinkle shell & Decreased & Decreased & - & - & $\begin{array}{l}\text { Falade (1995), Adewuyi and Adegoke } \\
\text { (2008) }\end{array}$ \\
\hline Mussel shell & Increase & Increase & - & - & Lertwattanaruk et al. (2012) \\
\hline Scallop shell & Decreased & & & & Cuadrado-Rica et al. (2016) \\
\hline
\end{tabular}

TABLE 7 | The influence of aquaculture waste on the durability of concrete.

\begin{tabular}{|c|c|c|c|c|c|}
\hline \multirow[t]{2}{*}{ Aquaculture waste } & \multicolumn{4}{|c|}{ Concrete durability } & \multirow[t]{2}{*}{ References } \\
\hline & Freeze-thaw resistance & Water permeability & Carbonization & Chemical attack & \\
\hline Oyster shell & Some improvement & Some improvement & No obvious effect & No obvious effect & Yang et al. (2010), Eo and Yi (2015) \\
\hline Periwinkle shell & - & - & - & Obvious impact (Ash) & Umoh and Olusola (1979) \\
\hline Scallop shell & No obvious effect & - & - & - & Wang et al. (2020) \\
\hline
\end{tabular}

and mortar, Shafigh et al. (2011a) also proposed to crush palm shell to $0.15-8 \mathrm{~mm}$ particles, and used a screen to remove smaller-than$2.36 \mathrm{~mm}$ particles to prepare high-strength concrete.

The porous structure of palm shell provides palm shell concrete good thermal insulation properties (Shafigh et al., 2012a). Under heat treatment, the surface quality of palm shell concrete can be changed, and the expansion and contraction of the material can be reduced, thereby improving the dimensional stability and bioresistance, permeability of palm shell concrete, and reducing the equilibrium moisture content (Yew et al., 2014). With the increase of heat treatment temperature and heat treatment time, the workability of palm shell concrete could also been improved (Yew et al., 2014).

\section{Rubber Seed Shell}

Malaysian annual production of rubber seed is projected to be 1.2 million metric tons there by indicating that freely availability of this material can be used in concrete industry. Since rubber seed shell (see Figure 7) is lighter, Muthusamy et al. (2014) studied the possibility of using rubber seed shells as an alternative material as coarse aggregates in concrete. As the number of rubber seed shells increases, the performance of concrete gradually decreases. Besides the low density of the concrete, this performance degradation is also related to the inability of the cement slurry to cover the aggregate uniformly. About $10 \%$ of the rubber seed shells are suitable as coarse aggregates for concrete preparation. In addition, Luhar et al. (2019) used fibers extracted from waste rubber tires to replace the sand in the mixture, which opened a new development path for the development of rubber-based concrete.

\section{AQUACULTURE WASTE}

This chapter reviews the application of aquaculture waste in concrete. Generally speaking, most kinds of aquaculture waste are shells which refer to the similar utilization ways in construction materials. A comparative study was carried out on the utilization of oysters, periwinkle, mussels and scallops as cement substitutes. It is found that all grated shells contained 96-97\% $\mathrm{CaCO}_{3}$ (Lertwattanaruk et al., 2012). The substitution and mixing amount of aquaculture waste in concrete in reviewed literatures are shown in Figure 12. The workability, mechanical properties of aquaculture waste concrete are summarized in Table $\mathbf{6}$, the durability of aquaculture waste concrete in Table 7, and the usage of aquaculture waste in concrete in Table 8.

\section{Oyster Shell}

Oysters are the world's largest cultured shellfish and one of the important marine biological resources available to humans. Globally, the waste oyster shell could amount to about 200,000 ton per year. Oyster shells (see Figure 12) contain more than $90 \%$ $\mathrm{CaCO}_{3}$, which is a precious resource.

Oyster shells can be used as coarse aggregates in concrete. The high replacement of oyster shells in concrete may have a negative impact on the long-term strength and elastic modulus of concrete (Yang et al., 2010; Martínez-García et al., 2017; Mo et al., 2018), resulting from the increase of the air content in concrete (Eo and $\mathrm{Yi}, 2015)$. When the amount of oyster shell is appropriate, the early compressive strength of concrete mixed with oyster shell will not decrease (Yang et al., 2005). In addition, the elastic modulus of oyster shell concrete decreases with the increase of oyster shell thickness. Considered both strength and workability, $10 \sim 13 \mathrm{~mm}$ is supposed to be the best particle size range for oyster shells as coarse aggregates (Eo and Yi, 2015).

The surface of oyster shell sand is relatively irregular, which means that particle friction is prone to affect the fluidity of 
TABLE 8 | Usage of aquaculture waste in concrete.

\begin{tabular}{|c|c|c|c|}
\hline Waste products & Usage & $\begin{array}{l}\text { Effect of usage } \\
\text { of waste materials } \\
\text { in concrete }\end{array}$ & References \\
\hline \multirow[t]{7}{*}{ Oyster shell } & Cement & $\begin{array}{l}\text { Setting time increased } \\
\text { Compressive strength reduced } \\
\text { Drying shrinkage reduced } \\
\text { Thermal conductivity reduced }\end{array}$ & Lertwattanaruk et al. (2012) \\
\hline & Sand & $\begin{array}{l}\text { Similar compressive strength using small particle size OS } \\
\text { Compressive strength decreased using large particle size OS }\end{array}$ & Yoon et al. (2004) \\
\hline & & $\begin{array}{l}\text { Workability reduced } \\
\text { No effect on setting time } \\
\text { Early strength increased } \\
28 \text { days tensile strength decreased } \\
28 \text { days MOE decreased }\end{array}$ & Yang et al. (2005) \\
\hline & & $\begin{array}{l}\text { No effect on } 28 \text { days compressive strength } \\
28 \text { days MOE decreased } \\
\text { Drying shrinkage increased } \\
\text { Freeze-thaw resistance improved } \\
\text { No effect on carbonation } \\
\text { No effect on chemical resistance } \\
\text { Water permeability resistance improved }\end{array}$ & Yang et al. (2010) \\
\hline & & $\begin{array}{l}\text { Workability reduced } \\
\text { Compressive strength increased at } 5 \% \text { replacement level } \\
\text { strength reduced at higher replacement level } \\
\text { Shrinkage increased } \\
\text { Sulfate resistance reduced }\end{array}$ & Kuo et al. (2013) \\
\hline & & $\begin{array}{l}\text { No effect on drying shrinkage } \\
\text { Compressive strength decreased } \\
\text { Tensile strength decreased }\end{array}$ & Eo and Yi (2015) \\
\hline & Coarse aggregate & $\begin{array}{l}\text { Workability reduced } \\
\text { Drying shrinkage increased } \\
\text { Compressive strength decreased } \\
\text { Tensile strength decreased }\end{array}$ & Eo and Yi (2015) \\
\hline \multirow[t]{3}{*}{ Periwinkle shell } & Cement & $\begin{array}{l}\text { Compressive strength decreased } \\
\text { Improved resistance towards magnesium sulfate attack }\end{array}$ & Umoh and Olusola (1979) \\
\hline & Coarse aggregate & $\begin{array}{l}\text { Workability reduced } \\
\text { Compressive strength decreased } \\
\text { Flexural strength decreased } \\
\text { Density decreased }\end{array}$ & Falade (1995) \\
\hline & & $\begin{array}{l}\text { Workability reduced } \\
\text { Compressive strength decreased } \\
\text { Density decreased }\end{array}$ & Adewuyi and Adegoke (2008) \\
\hline \multirow[t]{2}{*}{ Mussel shell } & Cement & $\begin{array}{l}\text { Setting time increased } \\
\text { Compressive strength reduced } \\
\text { Drying shrinkage reduced } \\
\text { Thermal conductivity reduced }\end{array}$ & Lertwattanaruk et al. (2012) \\
\hline & Sand & Compressive strength increased & Chin-Peow et al. (2015) \\
\hline Scallop shell & Coarse aggregate & $\begin{array}{l}\text { Increased the porosity of concrete } \\
\text { Facilitate fluid and chloride ion migration } \\
\text { Good frost resistance }\end{array}$ & $\begin{array}{l}\text { Cuadrado-Rica et al. (2016) } \\
\text { Wang et al. (2020) }\end{array}$ \\
\hline
\end{tabular}

cementitious mortar and reduce the working performance of cementitious mortar during the mixing process (Wang et al., 2013). When the content of oyster shell sand reached $20 \%$ replacement ratio of natural sand in cementitious mortar, the compressive strength of cementitious mortar does not decrease significantly (Kuo et al., 2013). Fly ash is beneficial to make up for the material structure defects caused by replacing natural aggregate sand with oyster shell sand. In terms of the long-term durability, due to the existence of oyster shells, the freeze-thaw resistance and water permeability of the concrete have also been improved. Fine oyster shell particles can fill the holes scattered in the concrete. However, oyster shells have no obvious effect on the carbonization and chemical erosion of the concrete (Yang et al., 2010).

The fineness of oyster shells is normally higher than that of other shells. Compared with ordinary mortar, mixing Portland cement with ground oyster shell reduces the shrinkage rate of the mortar. Specifically, the shrinkage rate of mortar mixed with ground oyster shell is higher than that of mortar mixed with ground periwinkle shell (Lertwattanaruk et al., 2012). 


\section{Periwinkle Shell}

Periwinkle shells are rich in calcium and easily combined with cement products (Adewuyi and Adegoke, 2008). In the 1990s, periwinkle shells (see Figure 12) were used to produce medium-strength lightweight concrete (Falade, 1995). However, as the content of the periwinkle shells increases, the proportion of cement slurry is not enough to form an effective combination with the periwinkle shells, since a large amount of periwinkle shells with rough surface cannot combine well with the mortar. This will not only reduce the compressive and flexural strength, but also reduce the workability and density of the concrete.

The strength of periwinkle shells concrete depends on the performance and replacement rate of periwinkle shell (Adewuyi and Adegoke, 2008). Researchers found that when the mix ratios are 1:1:2, 1:2:3 and 1:2:4, the periwinkle shell concrete can reach the minimum strength recommended for lightweight concrete, and the mix ratio is 1:1:2 has the highest compressive strength, up to $25.67 \mathrm{~N} / \mathrm{mm}^{2}$ (Osarenmwinda and Awaro, 2009). It provides a reference for the use of periwinkle shells replacing coarse aggregate in concrete.

Periwinkle shells could be calcined to produce periwinkle shell ash. Umoh (Umoh and Olusola, 1979) replaced 0-40\% of the cement volume with periwinkle shell ash. Sulfate concentration, periwinkle shell ash content and exposure time all affect the compressive strength of concrete. The effect of $\mathrm{MgSO}_{4}$ solution on ordinary concrete is more serious than the concrete mixed with periwinkle shell ash. In addition, it is expected that the strength loss of periwinkle shell ash concrete will be alleviated when the volcanic ash completely consumes harmful hydration products. When periwinkle shell ash content reaches $10 \%$, the concrete shows the best mechanical and durability performance.

\section{Mussel Shell}

Mussels living on coastal rocks are bivalve mollusks with dark brown shells. Mussel shells are wedge-shaped, with a pointed front end and a broad and round back end. The mussels shell is generally $6-8 \mathrm{~cm}$ long. Judging from the chemical composition of mussel shells, it does not have the properties of volcanic ash, but it is very possible to extract limestone from mussel shells.

It is found that the powdered mussel shells contains $96 \%$ $\mathrm{CaCO}_{3}$ and a small amount of impurities indicating that the limestone obtained from mussel shells can be used as mortar aggregate. The abrasive particles of mussel shells are in the shape of slender needles, resulting in a network structure with small pores in the interior of the mussel mortar (see Figure 12). This property can improve the mechanical properties of concrete (Ballester et al., 2007). The compressive strength of the mortar mixed with mussel shells is not as good as the mortar mixed with periwinkle shells and oyster shells. Nevertheless, from the perspective of practical application, the incorporation of mussel shells is sufficient for the compressive strength of mortar. By mixing ground mussel shells with mortar, the water consumption of the mortar can be reduced whilst the workability and shrinkage rate of the mortar can be improved (Lertwattanaruk et al., 2012).

However, the flat and flaky shape of mussel shells will increase the water demand and decrease the slump value of concrete, and also affect the paste-aggregate bond. Martínez-García et al. (2017) found that the organic matter in the composition of mussel shells would reduce the aggregate-slurry bonding force, increase the porosity, and affect the hydration process in concrete. In addition, the presence of organic matter will delay the coagulation and increase the viscosity of the slurry, thereby reducing the fluidity of the mixture.

\section{Scallop Shell}

Scallop shells are mostly in the shape of discs or fans. Soluble substances exuded from the crushed scallop shells, which affected the performance of the gelled slurry (Cuadrado-Rica et al., 2016). This may be the reason for the mechanical properties degradation and the porosity increasing of the concrete. However, the performance of scallop shell concrete can be improved by adjusting the mix ratio.

The chitin on the surface of scallop shell can form a compact structure, which protects the scallop shell and beneficial to its freeze-thaw resistance. At the end of the freeze-thaw cycle, the scallop shell concrete is almost intact and there is almost no damage to the inside of the scallop shell concrete (Wang et al., 2020). The freeze-thaw resistance of scallop shells provides basis for future development of building materials that can cope with low temperature conditions.

\section{CONCLUSION}

From the perspective of practical application, this paper comprehensively analyzes the development of agricultural waste and aquaculture waste in the field of construction materials in recent years, and summarizes the mature research findings through classification.

In summary, different agricultural wastes and aquaculture wastes are both currently showing great potential in the concrete field. From the point of view of utilization ways, it can be roughly divided into cement replacement, aggregate replacement and fiber reinforcement. The characteristics of these wastes can basically meet the requirements in terms of the substitution of different functional concrete components. From the perspective of profitability, agricultural and aquaculture waste can bring extremely low cost to the production of concrete. From the perspective of usability, most of the waste can improve the working performance, mechanical properties, and durability of concrete. However, the incorporation of the waste may also reduce certain properties of concrete (such as workability, strength and durability, etc., see Tables 2, 3, 5, 8). According to a large number of experiments, the mechanical and durability performance of the concrete with these wastes can be improved by controlling the amount of the waste. At the same time, the selection of waste materials also affects the performance of waste concrete. For example, waste materials from different regions and different maturity levels show very 
different properties. Different pre-treatment methods for waste materials will also cause corresponding deviations in test results. Therefore, selecting appropriate test materials and adopting appropriate pre-treatment methods will help improve the mechanical properties and durability of waste concrete.

Agricultural waste and aquaculture waste have great value in the development of environment-friendly concrete. Making full use of these waste resources can not only reduce the environmental pressure caused by waste accumulation and incineration, but also prevent natural resource depletion and shortages caused by excessively quarrying and mining aggregate, as well as the ecological environment pollution caused by carbon dioxide emissions. In the future, more and more wastes will be reused in the field of building materials, which will be a bright prospect for sustainable development.

\section{REFERENCES}

Adesanya, D. A., and Raheem, A. A. (2009a). A Study of the Workability and Compressive Strength Characteristics of Corn Cob Ash Blended Cement concrete. Construction Building Mater. 23 (1), 311-317. doi:10.1016/ j.conbuildmat.2007.12.004

Adesanya, D. A., and Raheem, A. A. (2009b). Development of Corn Cob Ash Blended Cement. Construction Building Mater. 23 (1), 347-352. doi:10.1016/ j.conbuildmat.2007.11.013

Adewuyi, A. P., and Adegoke, T. (2008). Exploratory Study of Periwinkle Shells as Coarse Aggregates in Concrete Works. J. Appl. Sci. Res. 4 (12), 1678-1681. Available at http://www.arpnjournals.com/jeas/research_papers/rp_2008/jeas_ 1208_136.pdf

Agarwal, A., Nanda, B., and Maity, D. (2014). Experimental Investigation on Chemically Treated Bamboo Reinforced Concrete Beams and Columns. Construction Building Mater. 71, 610-617. doi:10.1016/j.conbuildmat.2014.09.011

Ahmmad, R., Jumaat, M. Z., Bahri, S., and Islam, A. B. M. S. (2014). Ductility Performance of Lightweight Concrete Element Containing Massive palm Shell Clinker. Construction Building Mater. 63, 234-241. doi:10.1016/ j.conbuildmat.2014.04.022

Al-Akhras, N. M., and Abdulwahid, M. Y. (2010). Utilisation of Olive Waste Ash in Mortar Mixes. Struct. Concrete. 11 (4), 221-228. doi:10.1680/stco.2010.11.4.221

Al-Akhras, N. M., and Abu-Alfoul, B. A. (2002). Effect of Wheat Straw Ash on Mechanical Properties of Autoclaved Mortar. Cement Concrete Res. 32, 859-863. doi:10.1016/s0008-8846(02)00716-0

Al-Akhras, N. M., Al-Akhras, K. M., and Attom, M. F. (2008). Thermal Cycling of Wheat Straw Ash concrete. Proc. Inst. Civil Eng. - Construction Mater. 161 (1), 9-15. doi:10.1680/coma.2008.161.1.9

Al-Akhras, N. M., Al-Akhras, K. M., and Attom, M. F. (2009). Performance of Olive Waste Ash concrete Exposed to Elevated Temperatures. Fire Saf. J. 44 (3), 370-375. doi:10.1016/j.firesaf.2008.08.006

Al-Akhras, N. M. (2011). Durability Ofwheat Straw Ash Concrete Exposed to FreezeThaw Damage. Construction Mater. 164 (apr), 79-86. doi:10.1680/coma.900045

Alengaram, U. J., Mahmud, H., and Jumaat, M. Z. (2011). Enhancement and Prediction of Modulus of Elasticity of Palm Kernel Shell Concrete. Mater. Des. 32 (4), 2143-2148. doi:10.1016/j.matdes.2010.11.035

Alengaram, U. J., Muhit, B. A. A., and Jumaat, M. Z. b. (2013). Utilization of Oil Palm Kernel Shell as Lightweight Aggregate in Concrete - A Review. Construction Building Mater. 38 (38), 161-172. doi:10.1016/ j.conbuildmat.2012.08.026

Aprianti, E., Shafigh, P., Bahri, S., and Farahani, J. N. (2015). Supplementary Cementitious Materials Origin From Agricultural Wastes - A Review. Construction Building Mater. 74, 176-187. doi:10.1016/j.conbuildmat.2014.10.010

Augustine, A. S., and Tiza, M. (2016). Partial Replacement of Cement With Corn Cob Ash. Int. J. Innovative Res. Multidisciplinary Field. 2, 159-169. Available at http://www.ijirmf.com/wp-content/uploads/2016/11/201607034.pdf

\section{AUTHOR CONTRIBUTIONS}

Resources, WW; writing-original draft preparation, WYW; writing-review and editing, SG; supervision, GC; project administration, JY; investigation, YL All authors have read and agreed to the published version of the manuscript.

\section{FUNDING}

This research was funded by Youth Fund of Rocket Force University of Engineering (No. 2019QNJJ005); Back Analysis and Research of Surrounding Rock and Supporting Structure Parameters (No. 4166215); National Innovation Training Program for College Students (s202012715006); Youth Innovation Team of Shaanxi Universities (21JP138).

Ballester, P., Mármol, I., Morales, J., and Sánchez, L. (2007). Use of limestone Obtained From Waste of the Mussel Cannery Industry for the Production of Mortars. Cement Concrete Res. 37 (4), 559-564. doi:10.1016/ j.cemconres.2007.01.004

Bao, H. M., and Meng, H. Q. (2011). Experimental Study on Mechanical Properties of Sisal Fiber Concrete. Concrete. 3, 63-66. doi:10.3969/j.issn.10023550.2011.03.020

Belhadj, B., Bederina, M., Montrelay, N., Houessou, J., and Quéneudec, M. (2014). Effect of Substitution of Wood Shavings by Barley Straws on the PhysicoMechanical Properties of Lightweight Sand concrete. Construction Building Mater. 66, 247-258. doi:10.1016/j.conbuildmat.2014.05.090

Benmansour, N., Agoudjil, B., Gherabli, A., Kareche, A., and Boudenne, A. (2014). Thermal and Mechanical Performance of Natural Mortar Reinforced With Date palm Fibers for Use as Insulating Materials in Building. Energy and Buildings. 81, 98-104. doi:10.1016/j.enbuild.2014.05.032

Binici, H., Yucegok, F., Aksogan, O., and Kaplan, H. (2008). Effect of Corncob, Wheat Straw, and Plane Leaf Ashes as Mineral Admixtures on concrete Durability. J. Mater. Civ. Eng. 20 (7), 478-483. doi:10.1061/(asce)08991561(2008)20:7(478)

Biricik, H., Aköz, F., Berktay, I. 1., and Tulgar, A. N. (1999). Study of Pozzolanic Properties of Wheat Straw Ash. Cement Concrete Res. 29 (5), 637-643. doi:10.1016/s0008-8846(98)00249-x

Biricik, H., Aköz, F., Türker, F., and Berktay, I. (2000). Resistance to Magnesium Sulfate and Sodium Sulfate Attack of Mortars Containing Wheat Straw Ash. Cement Concrete Res. 30, 1189-1197. doi:10.1016/ s0008-8846(00)00314-8

Blankendaal, T., Schuur, P., and Voordijk, H. (2014). Reducing the Environmental Impact of concrete and Asphalt: a Scenario Approach. J. Clean. Prod. 66, 27-36. doi:10.1016/j.jclepro.2013.10.012

Bo, W., Yong, Y., and Chen, Z. P. (2018). Shape Effect on Compressive Mechanical Properties of Compound Concrete Containing Demolished Concrete Lumps. Construction Building Mater. 187, 50-64. doi:10.1016/ j.conbuildmat.2018.07.086

Carević, I., Serdar, M., Štirmer, N., and Ukrainczyk, N. (2019). Preliminary Screening of Wood Biomass Ashes for Partial Resources Replacements in Cementitious Materials. J. Clean. Prod. 229, 1045-1064. doi:10.1016/ j.jclepro.2019.04.321

Carević, I., Štirmer, N., Serdar, M., and Ukrainczyk, N. (2021). Effect of Wood Biomass Ash Storage on the Properties of Cement Composites. Materials. 14, 1632. doi: $10.3390 / \mathrm{ma} 14071632$

Cheah, C. B., and Ramli, M. (2011). The Implementation of wood Waste Ash as a Partial Cement Replacement Material in the Production of Structural Grade concrete and Mortar: an Overview. Resour. Conservation Recycling. 55 (7), 669-685. doi:10.1016/j.resconrec.2011.02.002

Chen, Y., Liang, Y. Z., and Liu, D. X. (2015). Influence of Plant Fiber Reinforcement on Frost Resistance and Durability of Vegetation concrete. Hubei Agric. Sci. 54 (19), 4840-4843. doi:10.14088/j.cnki.issn0439-8114.2015.19.048 
Chin-Peow, W., Poi-Ngian, S., and Tahir, M. M. (2015). Compressive Strength of Ground Waste Seashells in Cement Mortars for Masonry and Plastering. Appl. Mech. Mater. 727-728, 167-170. doi:10.4028/www.scientific.net/AMM.727728.167

Cordeiro, G. C., and Sales, C. P. (2015). Pozzolanic Activity of Elephant Grass Ash and its Influence on the Mechanical Properties of concrete. Cement and Concrete Composites. 55, 331-336. doi:10.1016/j.cemconcomp.2014.09.019

Correia, V. d. C., Santos, S. F., Mármol, G., Curvelo, A. A. d. S., and Savastano, H. (2014). Potential of Bamboo Organosolv Pulp as a Reinforcing Element in Fiber-Cement Materials. Construction Building Mater. 72, 65-71. doi:10.1016/ j.conbuildmat.2014.09.005

Cuadrado-Rica, H., Sebaibi, N., and Boutouil, M. (2016). Properties of Ordinary Concretes Incorporating Crushed Queen Scallop Shells. Mater. Structures. 49 (5), 1-12. doi:10.1617/s11527-015-0613-7

Cuenca, J., Rodríguez, J., Martín-Morales, M., Sánchez-Roldán, Z., and Zamorano, M. (2013). Effects of Olive Residue Biomass Fly Ash as Filler in SelfCompacting Concrete. Construction Building Mater. 40 (Mar), 702-709. doi:10.1016/j.conbuildmat.2012.09.101

Eo, S. H., and Yi, S. T. (2015). Effect of Oyster Shell as an Aggregate Replacement on the Characteristics of Concrete. Mag. Concrete Res. 67 (15), 1-10. doi: $10.1680 /$ macr. 14.00383

Falade, F. (1995). An Investigation of Periwinkle Shells as Coarse Aggregate in concrete. Building Environ. 30 (4), 573-577. doi:10.1016/0360-1323(94) 00057-y

Flávio de, A. S., Mobasher, B., and Soranakom, C. (2011). Effect of Fiber Shape and Morphology on Interfacial Bond and Cracking Behaviors of Sisal Fiber Cement Based Composites. Cement \& Concrete Composites. 33 (8), 814-823. doi:10.1016/j.cemconcomp.2011.05.003

Flower, D. J. M., and Sanjayan, J. G. (2007). Green House Gas Emissions Due to concrete Manufacture. Int. J. Life Cycle Assess. 12 (5), 282-288. doi:10.1065/ lca2007.05.327

Frías, M., Savastano, H., Villar, E., Sánchez de Rojas, M. I., and Santos, S. (2012). Characterization and Properties of Blended Cement Matrices Containing Activated Bamboo Leaf Wastes. Cement and Concrete Composites. 34 (9), 1019-1023. doi:10.1016/j.cemconcomp.2012.05.005

Ganesan, K., Rajagopal, K., and Thangavel, K. (2007). Evaluation of Bagasse Ash as Supplementary Cementitious Material. Cement and Concrete Composites. 29 (6), 515-524. doi:10.1016/j.cemconcomp.2007.03.001

Gunasekaran, K., Annadurai, R., and Kumar, P. S. (2012). Long Term Study on Compressive and Bond Strength of Coconut Shell Aggregate concrete. Construction Building Mater. 28 (1), 208-215. doi:10.1016/j.conbuildmat.2011.08.072

Gunasekaran, K., Annadurai, R., and Kumar, P. S. (2013a). Plastic Shrinkage and Deflection Characteristics of Coconut Shell Concrete Slab. Construction Building Mater. 43 (jun), 203-207. doi:10.1016/j.conbuildmat.2013.02.019

Gunasekaran, K., Annadurai, R., and Kumar, P. S. (2013b). Study on Reinforced Lightweight Coconut Shell Concrete Beam Behavior under Flexure. Mater. Des. 46 (Apr), 157-167. doi:10.1016/j.matdes.2012.09.044

Gunasekaran, K., Ramasubramani, R., Annadurai, R., and Prakash Chandar, S. (2014). Study on Reinforced Lightweight Coconut Shell Concrete Beam Behavior under Torsion. Mater. Des. 57, 374-382. doi:10.1016/ j.matdes.2013.12.058

Hou, P., Muzenda, T. R., Li, Q., Chen, H., Kawashima, S., Sui, T., et al. (2021). Mechanisms Dominating Thixotropy in limestone Calcined Clay Cement (LC3). Cement Concrete Res. 140, 106316. doi:10.1016/j.cemconres.2020.106316

Kanning, R. C., Portella, K. F., and Costa, M. R. M. D. (2011). Evaluation of Pozzolanic Activity of Banana Leaf Ash. Portugal: International Conference on Durability of Building Materials and Components, Porto.

Kanning, R. C., Portella, K. F., Bragança, M. O. G. P., Bonato, M. M., and dos Santos, J. C. M. (2014). Banana Leaves Ashes as Pozzolan for Concrete and Mortar of Portland Cement. Construction Building Mater. 54, 460-465. doi:10.1016/j.conbuildmat.2013.12.030

Kriker, A., Bali, A., Debicki, G., Bouziane, M., and Chabannet, M. (2008). Durability of Date Palm Fibres and Their Use as Reinforcement in Hot Dry Climates. Cement and Concrete Composites. 30 (7), 639-648. doi:10.1016/ j.cemconcomp.2007.11.006

Kriker, A., Debicki, G., Bali, A., Khenfer, M. M., and Chabannet, M. (2005). Mechanical Properties of Date palm Fibres and concrete Reinforced With Date palm Fibres in Hot-Dry Climate. Cement and Concrete Composites. 27 (5), 554-564. doi:10.1016/j.cemconcomp.2004.09.015

Kuo, W.-T., Wang, H.-Y., Shu, C.-Y., and Su, D.-S. (2013). Engineering Properties of Controlled Low-Strength Materials Containing Waste Oyster Shells. Construction Building Mater. 46 (8), 128-133. doi:10.1016/ j.conbuildmat.2013.04.020

Lertwattanaruk, P., Makul, N., and Siripattarapravat, C. (2012). Utilization of Ground Waste Seashells in Cement Mortars for Masonry and Plastering. J. Environ. Manage. 111, 133-141. doi:10.1016/j.jenvman.2012.06.032

Li, Y., Mai, Y.-W., and Ye, L. (2000). Sisal Fibre and its Composites: a Review of Recent Developments. Composites Sci. Technology. 60 (11), 2037-2055. doi:10.1016/s0266-3538(00)00101-9

Liu, B., Ji, T., and Zhang, L. Z. (2013). Study on the Compressive and Flexural Properties of Jute Fiber Reinforced concrete. Tech. textiles. 4, 43-45.

Luhar, S., Chaudhary, S., and Luhar, I. (2019). Development of Rubberized Geopolymer Concrete: Strength and Durability Studies. Construction Building Mater. 204 (APR.20), 740-753. doi:10.1016/ j.conbuildmat.2019.01.185

Mannan, M. A., and Ganapathy, C. (2004). Concrete From an Agricultural WasteOil Palm Shell (Ops). Building Environ. 39 (4), 441-448. doi:10.1016/ j.buildenv.2003.10.007

Martínez-García, C., González-Fonteboa, B., Martínez-Abella, F., and Carro- López, D. (2017). Performance of Mussel Shell as Aggregate in plain concrete. Construction Building Mater. 139, 570-583. doi:10.1016/j.conbuildmat.2016.09.091

Merta, I., and Tschegg, E. K. (2013). Fracture Energy of Natural Fibre Reinforced Concrete. Construction Building Mater. 40, 991-997. doi:10.1016/ j.conbuildmat.2012.11.060

Mo, K. H., Alengaram, U. J., Jumaat, M. Z., Lee, S. C., Goh, W. I., and Yuen, C. W. (2018). Recycling of Seashell Waste in Concrete: a Review. Construction Building Mater. 162, 751-764. doi:10.1016/j.conbuildmat.2017.12.009

Mo, K. H., Johnson Alengaram, U., Jumaat, M. Z., and Yap, S. P. (2015). Feasibility Study of High Volume Slag as Cement Replacement for Sustainable Structural Lightweight Oil palm Shell concrete. J. Clean. Prod. 91, 297-304. doi:10.1016/ j.jclepro.2014.12.021

Muthusamy, K., Nordin, N., Vesuvapateran, G., Ali, M., Mohd Annual, N. A Harun, H., et al. (2014). Exploratory Study of Rubber Seed Shell as Partial Coarse Aggregate Replacement in concrete. Rjaset. 7 (6), 1199-1202. doi:10.19026/rjaset.7.380

Nakanishi, E. Y., Frías, M., Martínez-Ramírez, S., Santos, S. F., Rodrigues, M. S., Rodríguez, O., et al. (2014). Characterization and Properties of Elephant Grass Ashes as Supplementary Cementing Material in Pozzolan/Ca(OH)2 Pastes. Construction Building Mater. 73, 391-398. doi:10.1016/ j.conbuildmat.2014.09.078

Olanipekim, E. A., Olusola, K. O., and Ata, O. (2006). A Comparative Study of Concrete Properties Using Coconut Shell and Palm Kernel Shell as Coarse Aggregates. Building Environ. 41 (3), 297-301. doi:10.1016/ j.buildenv.2005.01.029

Osarenmwinda, J. O., and Awaro, A. O. (2009). The Potential Use of Periwinkle Shell as Coarse Aggregate for concrete. Adv. Mater. Res. 62-64, 39-43. doi:10.4028/www.scientific.net/amr.62-64.39

Pacheco-Torgal, F., and Jalali, S. (2011). Cementitious Building Materials Reinforced With Vegetable Fibres: a Review. Construction Building Mater. 25 (2), 575-581. doi:10.1016/j.conbuildmat.2010.07.024

Phatak, U. J., Abhijit, A., and Patil, A. (2014). Assesement of concrete by Replacing Coarse Aggregate and fine Aggregate to Coconut Shell and Glass Sand for Economical and Eco-Friendly concrete. Indian J. Appl. Res. 4, 31-33. doi:10.15373/2249555X/APR2014/54

Pinto, J., Vieira, B., Pereira, H., Jacinto, C., Vilela, P., Paiva, A., et al. (2012). Corn Cob Lightweight Concrete for Non-Structural Applications. Construction Building Mater. 34, 346-351. doi:10.1016/j.conbuildmat.2012.02.043

Ramakrishna, G., and Sundararajan, T. (2005a). Impact Strength of a Few Natural Fibre Reinforced Cement Mortar Slabs: a Comparative Study. Cement and Concrete Composites. 27 (5), 547-553. doi:10.1016/j.cemconcomp.2004.09.006

Ramakrishna, G., and Sundararajan, T. (2005b). Studies on the Durability of Natural Fibres and the Effect of Corroded Fibres on the Strength of Mortar. Cement and Concrete Composites. 27 (5), 575-582. doi:10.1016/ j.cemconcomp.2004.09.008 
Ramaswamy, H. S., Ahuja, B. M., and Krishnamoorthy, S. (1983). Behaviour of concrete Reinforced With Jute, Coir and Bamboo Fibres. Int. J. Cement Composites Lightweight Concrete. 5 (1), 3-13. doi:10.1016/0262-5075(83) 90044-1

Ramos, T., Matos, A. M., and Sousa-Coutinho, J. (2013). Mortar With Wood Waste Ash: Mechanical Strength Carbonation Resistance and Asr Expansion. Construction Building Mater. 49 (dec), 343-351. doi:10.1016/ j.conbuildmat.2013.08.026

Reddy, B. D., Jyothy, S. A., Jyothy, S. A., and Shaik, F. (2014). Experimental Analysis of the Use of Coconut Shell as Coarse Aggregate. Iosrjmce. 10 (6), 06-13. doi:10.9790/1684-1060613

Romildo, D. T. F., Khosrow, G., and Miguel, A. S. (2005). Restrained and Drying Shrinkage of Cement Mortar Composites Reinforced With Vegetable Fibres. Cement and Concrete Composites. 27, 537-546. doi:10.1016/ j.cemconcomp.2004.09.005

Rukzon, S., and Chindaprasirt, P. (2012). Utilization of Bagasse Ash in HighStrength Concrete. Mater. Des. 34 (Feb), 45-50. doi:10.1016/ j.matdes.2011.07.045

Safiuddin, M., Salam, M. A., and Jumaat, M. Z. (2011). Utilization of Palm Oil Fuel Ash in Concrete: a Review/Palmi Aliejaus Kuro Pelenų Naudojimas Betone. Apžvalga. J. Civil Eng. Management. 17 (2), 234-247. doi:10.3846/ 13923730.2011.574450

Salmabanu, L., Ta-Wui, C., and Ismail, L. (2019). Incorporation of Natural Waste From Agricultural and Aquacultural Farming as Supplementary Materials With Green Concrete: a Review. Composites B: Eng. 175, 107076. doi:10.1016/ j.compositesb.2019.107076

Shafigh, P., Jumaat, M. Z., Mahmud, H. B., and Alengaram, U. J. (2011a). A New Method of Producing High Strength Oil palm Shell Lightweight concrete. Mater. Des. 32 (10), 4839-4843. doi:10.1016/j.matdes.2011.06.015

Shafigh, P., Jumaat, M. Z., and Mahmud, H. (2011b). Oil Palm Shell as a Lightweight Aggregate for Production High Strength Lightweight concrete. Construction Building Mater. 25 (4), 1848-1853. doi:10.1016/ j.conbuildmat.2010.11.075

Shafigh, P., Jumaat, M. Z., Mahmud, H. B., and Hamid, N. A. A. (2012a). Lightweight Concrete Made From Crushed Oil palm Shell: Tensile Strength and Effect of Initial Curing on Compressive Strength. Construction Building Mater. 27 (1), 252-258. doi:10.1016/j.conbuildmat.2011.07.051

Shafigh, P., Mahmud, H. B., and Jumaat, M. Z. (2012b). Oil Palm Shell Lightweight Concrete as a Ductile Material. Mater. Des. (1980-2015). 36 (Apr), 650-654. doi:10.1016/j.matdes.2011.12.003

Shafigh, P., Mahmud, H. B., Jumaat, M. Z., and Zargar, M. (2014). Agricultural Wastes as Aggregate in Concrete Mixtures - A Review. Construction Building Mater. 53 (feb.28), 110-117. doi:10.1016/j.conbuildmat.2013.11.074

Siddique, R. (2012). Utilization of Wood Ash in Concrete Manufacturing. Resour. Conservation Recycling. 67, 27-33. doi:10.1016/j.resconrec.2012.07.004

Silva, F. d. A., Filho, R. D. T., Filho, J. d. A. M., and Fairbairn, E. d. M. R. (2010). Physical and Mechanical Properties of Durable Sisal Fiber-Cement Composites. Construction Building Mater. 24 (5), 777-785. doi:10.1016/ j.conbuildmat.2009.10.030

Singh, M., and Siddique, R. (2015). Properties of concrete Containing High Volumes of Coal Bottom Ash as fine Aggregate. J. Clean. Prod. 91 (mar.15), 269-278. doi:10.1016/j.jclepro.2014.12.026

Tomas, U., and Ganiron, J. R. (2013). Sustainable Management of Waste Coconut Shells as Aggregates in Concrete Mixture. J. Eng. Sci. Technology Rev. 6 (5), 7-14. doi:10.25103/jestr.065.02

Ukrainczyk, N., Vrbos, N., and Koenders, A, B. (2016). Reuse of Woody Biomass Ash Waste in Cementitious Materials. Chem.Biochem.Eng.Q. 30 (2), 137-148. doi:10.15255/cabeq.2015.2231

Umoh, A. A., and Odesola, I. (1979). Characteristics of Bamboo Leaf Ash Blended Cement Paste and Mortar. Civil Eng. Dimension. 17 (1). doi:10.9744/ CED.17.1.22-28

Umoh, A. A., and Olusola, K. O. (1979). Performance of Periwinkle Shell Ash Blended Cement Concrete Exposed to Magnesium Sulphate. Civil Eng. Dimension. 15 (2), 96-101. doi:10.9744/CED.15.2.96-101

van der Lugt, P., Van den Dobbelsteen, A. A. J. F., and Janssen, J. J. A. (2006). An Environmental, Economic and Practical Assessment of Bamboo as a Building Material for Supporting Structures. Construction Building Mater. 20 (9), 648-656. doi:10.1016/j.conbuildmat.2005.02.023
Wang, D. L., Yang, C., and Zhao, Q. X. (2020). Study on the Frost Resistance of Shell Waste Pervious Vegetation concrete. Journal of Yangtze River Scientific Research Institute. (accepted).

Wang, D. (2013). Study on the Production of Aerated Blocks With High Split Pressure Ratio and Low Shrinkage Value From Waste Hemp. New building Mater. 10, 8-13.

Wang, H.-Y., Kuo, W.-T., Lin, C.-C., and Po-Yo, C. (2013). Study of the Material Properties of Fly Ash Added to Oyster Cement Mortar. Construction Building Mater. 41 (apr), 532-537. doi:10.1016/j.conbuildmat.2012.11.021

Wang, W. H., Meng, Y. F., and Wang, D. Z. (2017). Experimental Study on the Influence of Rice Husk Ash on the Performance of Cement Base and concrete. China Rural Water Conservancy and Hydropower. 5, 42-44.

Xie, X., Zhou, Z., Jiang, M., Xu, X., Wang, Z., and Hui, D. (2015). Cellulosic Fibers From Rice Straw and Bamboo Used as Reinforcement of Cement-Based Composites for Remarkably Improving Mechanical Properties. Composites Part B: Eng. 78, 153-161. doi:10.1016/j.compositesb.2015.03.086

$\mathrm{Xu}, \mathrm{L}$. (2013). Research on Using Flax Fiber to Reduce Plastic Shrinkage and Cracking of Concrete. Concrete. 10, 91-94. doi:10.3969/ j.issn.1002-3550.2013.10.023

Yang, E.-I., Kim, M.-Y., Park, H.-G., and Yi, S.-T. (2010). Effect of Partial Replacement of Sand With Dry Oyster Shell on the Long-Term Performance of concrete. Construction Building Mater. 24 (5), 758-765. doi:10.1016/j.conbuildmat.2009.10.032

Yang, E.-I., Yi, S.-T., and Leem, Y.-M. (2005). Effect of Oyster Shell Substituted for Fine Aggregate on Concrete Characteristics: Part I. Fundamental Properties. Cement Concrete Res. 35 (11), 2175-2182. doi:10.1016/j.cemconres.2005.03.016

Yew, M. K., Mahmud, H. B., Ang, B. C., and Yew, M. C. (2014). Effects of Heat Treatment on Oil Palm Shell Coarse Aggregates for High Strength Lightweight concrete. Mater. Des. (1980-2015). 54, 702-707. doi:10.1016/j.matdes.2013.08.096

Yoon, H., Park, S., Lee, K., and Park, J. (2004). Oyster Shell as Substitute for Aggregate in Mortar. Waste Manag. Res. 22 (3), 158-170. doi:10.1177/ $0734242 \times 04042456$

Zeng, Z., Liu, Q. L., and Liu, B. H. (2018). Experimental Study on thermal Insulation Performance of Rape Straw Fiber concrete. Chin. Agric. Sci. Bull. 34 (35), 130-134.

Zhang, B., and Poon, C. S. (2015). Use of Furnace Bottom Ash for Producing Lightweight Aggregate Concrete With Thermal Insulation Properties. J. Clean. Prod. 99 (jul15), 94-100. doi:10.1016/j.jclepro.2015.03.007

Zhang, C. K. (2011). Application of Flax in Treatment of Leakage of Cofferdam AntiSeepage Wall in Jin'anqiao Hydropower Station. Yunnan Hydropower. 27 (5), 65-66. doi:10.3969/j.issn.1006-3951.2011.05.017

Zhang, L. Z., Liu, B., and Xu, Z. L. (2012). Compression and Crack Resistance of Jute Fiber Reinforced Cement Composite. Shanghai Textile Technology. 40 (12), 32-38. doi:10.16549/j.cnki.issn.1001-2044.2012.12.001

Zhang, X. (2015). Study on the Mechanical Properties and Durability of Rice Husk Ash Concrete. Concrete cement Prod. 11, 91-94. doi:10.19761/j.10004637.2015.11.022

Zheng, C. B., Ding, H. Z., and Du, Z. Y. (2018). The Influence of rice Husk Ash on the Performance of Concrete. Chongqing Architecture. 17, 58-60. doi:10.3969/ j.issn.1671-9107.2018.03.58

Conflict of Interest: The authors declare that the research was conducted in the absence of any commercial or financial relationships that could be construed as a potential conflict of interest.

Publisher's Note: All claims expressed in this article are solely those of the authors and do not necessarily represent those of their affiliated organizations, or those of the publisher, the editors and the reviewers. Any product that may be evaluated in this article, or claim that may be made by its manufacturer, is not guaranteed or endorsed by the publisher.

Copyright (c) 2021 Wang, Wei, Gao, Chen, Yuan and Li. This is an open-access article distributed under the terms of the Creative Commons Attribution License (CC BY). The use, distribution or reproduction in other forums is permitted, provided the original author(s) and the copyright owner(s) are credited and that the original publication in this journal is cited, in accordance with accepted academic practice. No use, distribution or reproduction is permitted which does not comply with these terms. 